THE EFFECT OF ROLES AND DEEDS ON RESPONSIBILITY JUDGMENTS:

THE NORMATIVE STRUCTURE OF WRONGDOING

V. Lee Hamilton and Joseph Sanders

University óf Michigan

July 1979

Copies available through: Center for Research on Social Organization University of Michigan

330 Packard Street

Ann Arbor, Michigan 48109 

THP EFFECT OF ROLES AND DEEDS IN RESPONSIBILITY JUDGMENTS:

THE NORMATIVE STRUCTURE OF WRONGDOING*

by

v. Lee Hamfliton

and

Joseph Sanders

The Untverst.ty of Michtigan

*The authors wish to thank both the students in the 1977 Detroit Area Study for thetr efforts in making the research possible and Dr. Robert Groves for flling the role. of director of the D.A.S. with grace, good humor, and good

scarch taboratory for suggesting the tactic of quast-1ndependent replications for the data analysis. The research was supported by seed funds from the Soctal Science Research Council and from the University of Michtgan in addition to the University's regular support of the D.A.S. Data analysis and wr 1ting were supported by N.S.F. Grant \# SOC 77-24918.

Addrcss all communications to Dr. v. Lee Ham1lton, Sociology Department, Unt.versity of Michtgan, Ann Arbor, Michtgan 48109.
Human fudgment of wrongdoing is a potential meeting ground for sociological models of norms and psychological models of cognition. The present paper discusses the theory of human responsibility judgments that has dominated psychology since Jean Plaget and expands on that theory from a soctological perspective. We of fer an alternative model, arguing that judgments of responsibility are functions of both the deeds an actor performs and the soclal expectations of others for the actor. Socially differentiated expectations, soclal roles, should therefore play a cruclal role in the fudgment of wrongdoing. Roles should serve as normative contexts that determine how other information is weighed and used. We Identify two dimensions of roles that may be determinants of responsibility judgments: the hterarchy and the solidarity of the actorvictim relationship. We report results from a survey in which experimentally varied vignettes included consideration of role relationships as well as traditional psychological factors (such as the actor's mental state). The study replicated resilts known since Plaget, pointing to the 1mportance of an actor's mental state when adults judge responsibility in comparison to the relatively trivial role of the act's consequences. But the findings also showed that roles alter the Interpretation and fudgment of wrongdoing, including the use of information about mental state. In particular, the normative model for judgment of persons in authority over victims differed substantially from the model for judgment of persons who were equals with their victims. The results indicate, as predicted, that no model of how humans fudge responsibility is complete without consideration of social roles and their normative demands. 
THE EFFECT OF ROLES AND DEEDS ON RESPONSIBILITY JUDGMENTS:

THE NORMATIVE STRUCTURE OF WRONGDOING

Responstbility for wrongdolng, a key category of human norms, is a central issue in both group social organtization and Individual social 1ife. Permeating a.1. legal systems, the concept of responsibility has long concerned philosophers. Soctologists have simflarly long been convinced that human fudgment of wrongdoing may be a key 1ssue in soctal control. But we still do not know how such judgments are made. This paper, after revlewing relevant theories of such fudgments, w111. formulate a socfological framework to examine norms about responstbility, and will then test this framework empirically.

Despite its importance, responsibility itself has only recently become an Issue for study in three fields: legal anthropology, sociology of law, and attribution theory in soclal psychology. Legal anthropologists have concentrated upon the social organtzation of groups to explain the process of responsthillty attribution (e.g., Gluckman, 1967; L1ewellen and Hoebe1, 1949; Nader, 1969). Legal sociologists have focused on status differences between actors and on the effect of bureaucratic organization on dispute settlement (e.g., Emcrson, 1.969; Nonet, 1969; Ross, 1970). Soctal. psychologists have studied responsthility judgments as cognftive processes, concentrating on individual differences among observers or on general models of how perceivers process Informat ion about deeds observed (e.g., Hetder, 1958; Shaw and Sulzer, 1964; Shaver, 1.970). In sum, legal anthropologists and soclologists have focused on organizational determinants of responsibility while social psychologists have concentrated on perceptions of individual deeds. Our approach merges these alternative foct into a stingle scheme which makes exp11c1t what is of ten Implifcit In discusstons of norms: the notion that norms as rules or standards are carried in people's hands. We focus on what determines fudgments by Individual respondents who assess ideal-typical instances of wrongdoing. Our goal is to bring soctological concepts into models of cognition about wrongdoing.

Our basic premise is that role expectations serve as normative contexts. within which people fudge the actions of themselves and others. Psychological studies Investigating responsibility fudgments have, by focusing on the actions of 1solated individuals, discounted the potential importance of social expectations as determinants of responsibility for wrongdoing. Since these studies rest on what have been claimed to be universal laws for such fudgments, it is important to examine the central theoretical tradition in psychology before turning to how sociological insights can yield a st 111 more general model.

Fritz Heider (1958), perhaps the foremost theoretictan in this area, built upon the work of Jean Plaget (1965[1932]) to produce a developmental model of five levels in responsibility judgments. ${ }^{1}$ At the Association level, a person merely associated with an event may be held responsible for 1t. At the Commission level a person may be held responsible for any effect caused, whether or not it is intentional or foreseeable by the actor. At the Foreseeability level a person is held responsible for any effect that could have been foreseen, even if it was not intended. At the Intentionality level, only fully intended acts are grounds for responsibility. And at the Justiflability level responsibility for even intentional acts may be reduced by the presence of environmental justifications or excuses.

Heider's proposed levels are a useful place to beg in a discussion of responsibility judgments. Yet one should note that the levels, although

they are la1d out as if on a cont lnuum, do not all address the same considerations. The second, third, and fourth levels bastcally speak to the 
actor's mental state in relation to a given act. The first and fifth address other considerations. The first, Assoctation, is concerned with the role relat lons between a person being fudged and some other person who actually commits the act. The fifth, Justiflability, is concerned with varfous situational circumstances which may alter a fudgment based solely upon an actor's mental state. Thus while the five levels may comprise a continuum in some developmental sense (1.e., children may in a general way move through these stages as their moral fudgment matures), they are not levcls in the conceptual sense that a higher level means there is more of something. To compare Intentionality and Justif iability, for instance, t.s to compare mental state to a host of situational excuses. A more sociological approach would argue that to understand responsibility judgments we must consider at least two distinct factors: what an actor did, and the soctal expectations of others for what the actor should have done. ${ }^{2}$ What an actor "did" may be approximated by traditional psychological variables such as the actor's intention and the act's consequences. But in order to know how an observer w111 fudge that deed, one also needs to know what was expected of the actor.

Social expectations may be considered at several levels. At the most abstract level are general expectations; norms which tend to apply to all Individuals (e.g., rules against homiclde) or are so general that they may appear to apply to all actors (such as the rules for safe driving that all drivers are supposed to know). At the other extreme are particularistic features of sltuations that can alter our view of what one should have done, and indeed of what one did in fact do. These "contextual" features can Incl.ude aspects of the actor's blography (such as how he or she has acted in the past) or inputs that third parties bring to a situation (such as persuasion attempts, orders, or coercion). At a middle level are expectations that are differentiated by soctal position. These are soctal roles.
A more soclologically informed model of human responsibility fudgments must therefore attempt to specify which roles may produce differential expectations, and how these in turn lead to different attributions of responsibility. Roles, however, can be analyzed Into a bewildering varfety of categories and according to a wide variety of perspectives (e.g., Biddle and Thomas, 1966; Sarbin and Allen, 1968). Are there any differences among roles that are generally appropriate for a model of responsibility judgments? We bel leve that there are at least two such differences: those based on the dimenstons of hierarchy and solidarity. We shall briefly examine evidence of related 1inguistic distinctions, as indicators of the everyday Importance of these differences among roles; legal rules, as Indicators of how responsibility and sanctioning judgments may be formally differentlated along these dimensions; and soctological theortes themselves, as Indicators that informed observers of social structure find these to be useful distinctions among role relationships.

Linguistic distinctions based on role positions provide at least prima facie evidence of the importance of certain social categories to humans. In this regard Brown (1965) has argued that there are, crossculturally, two fundamental dimensions to norms of address (words and titles people use in speaking to one another). The dimenstion of hierarchy between Individuals ts reflected in rules 1nvolving the superiority of one speaker to another. ${ }^{3}$ And the dimension of solidarity ts reflected in rules Involving the personal closeness of speakers. As Brown notes, there have been fascinating historical changes in such rules, particularly in the form of shifts toward equal and close forms (e.g., "comrade") as a result of industrialization and revolution. It remains the case, however that modern languages reveal a full range of use of the two dimensions of address--from the Japanese multiple levels of hierarchy, ${ }^{4}$ through the complexittes of 
politely juggling the French tu and vous or the German du and Ste, to the nicitics of "first naming" versus more formal titles in English. The fact that people use these 1.1nguistic dimensions dally suggests they may base certain social. expectations on the distinct fons they draw.

The law Incorporates hierarchy in formal decisions about responsibility. Legally subordinate and superior positions are frequent1y treated differently from equal ones. Both military and civil law hold superiors responstble for actions conducted at low levels of intentionality. Vicarious 11ability (Helder's assoctation level) and strict llability (Helder's comission level) rules are typically employed against corporations, employers, generals, parents and presidents--not against average citizens who wrong their equals. ${ }^{5}$ Likewlse, sulordinates are sometimes provided with defenses when acting on the basls of supertor orders (c.f. Dinstein, 1.971).

Law also affords solidarity some recognittion. Sometimes this is in the form of nonrecognition: of fenses may be ignored or treated lentently if committed by one person closely tied to another. ${ }^{6}$ For example, rapes or assults may not be recognized between husband and wife. On the civil side, there has been a parallel. legal hesttation to recognize torts between members of a familiy. The primary justification for this reluctance has been that 1itigation would destroy the harmony of the household. ${ }^{7}$ For both criminal and civill tssues, people who are closely tied may themselves recognize the corrostve nature of the formal legal process and avold legal involvement where posstble (e.g., Macaulay, 1963). And procedures in places such as fam11.y court often try, with varying degrees of success, to restructure. the l.egal process to accommodate the nature of the relationship between those who are closely tied.

Finalliy, sociologists would agree that hierarchy is important. Whether one speaks in terms of power or authority, hierarchy is seen as a fundamental dimension in social relationships (e.g., Blau, 1964, Dahrendorf, 1959; Weber, 1947; Wesolowsk1, 1962). Hierarchy versus equality 1s an obvious property of roles, as the differences between parent-child or workeremployer dyads and palrs of stblings, friends or co-workers would suggest. But hierarchy alone does not account for all the differences between these dyads. When we compare parent-chlld to worker-employer, or brotherslster to two co-workers (or even more extremely to buyer-seller), a second dimenston emerges. Th1s dimension is related to Brown's notion of solidarity.

Because so many sociologists have used this solfdaritydimension there is no one label to describe 1t. For example, the movement from pre-modern to modern society has been variously characterized as a movement from Gemelnschaft to Gesellshaft (Tönntes, 1957); from traditional to rational-bureaucratic authority (Weber, 1947); and from law based on status to law resting on contract (Maine, 1963). Anthropologists simflarly distinguish between peasant life in multiplex relations and the change engendered by a cash economy (e.g., Nader, 1969; Wolf, 1969). In Parsontan (1951) terms one can speak of a movement from ascribed to achleved statuses; from particularistic to universalistic relations; and from diffuse to specific obligations.

While such concepts may be used to differentiate types of societies, they are also potentially relevant to describing role relationships within modern societies--such as in distinguishing parent-child from worker-employer relations. A final sallent example of a relevant distinction between modern role relations is Blau's (1964) discussion of intrinsic versus extrinsic exchanges. Intrinsic exchanges are particularly likely in the kinds of relations that anthropologists might call multiplex or Parsontans might call particularistic and diffuse. Thus many different social scientific terms appear to tap the linguistic distinction between solidary and non-solidary relations. From the viewpoint of modern soctal structure, each relates to differences in the type of tie between individuals. 
For convenfence in relating our terms to legal thought, we shall summarize this second dimension of soctal 1.1.fe by using Maine's (1963) contrast between status and contract relationships. Maine's original distinction focused on legal organization and particularly on property. We use the status-contract diatinction more broadly, referring to the full. range of interaction involving bonded group members (status) versus Individuals freely agreelng to an exchange (contract). In status-based rel.ntionships soctal ties are more extensive, permanent, unalterable, and individually unique. The parties share a collective identity (e.g., family) based on the bond of their relationship. In contract relationships the ties are more 11 mited, temporary, voluntary, and interchangeable.

The distinction between status and contract relations can, of course, be cross-cut by the distinction between hierarchy and equality. In the context of ongoing relationships, the hierarchy involved is generally one of anthority rather than sheer power. In most extreme form, then, four Ideal-typical role relations can be explored as potential determinants of the judgment of wrongdoing. 8

In sum, human fudgment of wrongdoing is an area where we might expect general. social norms to exist. We have argued that these norms should incorporate elements related to an actor's deed and elements related to soctal expectations for what the actor should have done. Since a primary concern for soctologists should be role-differentiated expectations, we identiffed two primary dimensions of social role relations that deserve attention as potential influences on assessments of wrongdoing: hierarchy and solidarity. These dimensions pervade language, law, and sociological theory 1tself. In the present paper we explore the effect of these role relattons on responsibility judgments, both as direct determinants of responsibilitity and as normative contexts that may alter the meaning or 1mpact of the deed-related variables generally studied by psychologists: the actor's mental state and the act's consequence. Both "main effects" of role and "interaction effects" between roles and deeds may prove 1mportant. In addition, we examine the impact of two contextual variables that may affect expectations: the presence of a past pattern of bad or good behavior by an actor and the presence or absence of Influence from enother person on the actor. These contextual features of action stand in an intermediate position between features of the act 1tself and features of the role relationship between the parties involved. As with mental state and consequences, the 1ssues for these contextual vartables are their direct impact on fudged responsibility and their potential for differential impact in different role contexts.

In the present study we obtained judgments of hypothetical stories concerning wrongdoing to assess the impact of roles and deeds on responstbility. Since Piaget (1965[1932]), such strategles have been used In psychology to ascertain the structure of cognition about wrongdoing. We also embedded experimental variations in these stories, which were then administered to a random sample survey of adults. This tactic, simflar to that recently used by Ross1 and colleagues (e.g., Alves and Rossi, 1978; Jasso and Ross1, 1977), combines the experiment's advantage of clearer causal inference with the survey's advantage of wider generallzability.

The Study

The data come from a probability sample survey of the Detro1t S.M.S.A. In the spring and summer of $1977(\mathrm{~N}=678)$. Data for the present study represented approximately half of the one-hour interview schedule for the 1977 Detrolt Area Study, ${ }^{9}$ plus supplemental information from a mallback questionnatre returned by approximately half of the respondents ( $N=349)$. 
Each subject heard six vignettes concerning some wrongdoing. Each vignette was itself an experiment. Versions of each story were randomly assigned to subjects, and In addition the order of presentation of stories was varied according to a Latin Square design to control for possible order effects. After hearing one version of a given story, each respondent was asked a series of questions. These included the responsibility of the actor for what happened, asked on an 11-point scale from $0=$ not at a11 responsible to $10=$ fully responsible; the appropriate sanction; manipulation checks on the experfmentally manipulated variables; and an open-ended question asking the respondent's perception of the most important determinant of responsibility.

Design. The two role relationship dimenstons, hierarchy and solidarity, were incorporated in four vignettes designed to represent each of the four ideal-typical. combinations. All respondents also heard two stories in which there was no prior relationship between the parties, one an automobile accident and the other an armed robbery. These were introduced to examine the effect of deed-related variables in the absence of role ties. ${ }^{10}$ pinally, the subjects were given a mailiback questionnalre containing an additional ten stories. These. Included both additional examples of role relationships and other more specialized topics. The present paper concentrates on the four core storles in the main interview. It also brief1y presents data from the automobile accident and armed robbery cases; and 1 ends with data from one maljback story in which role relationships were varied in a single setting.

The design of the four core stories is summartized in Table 1. The capitalized labels indicate the role pairs chosen for each type of relatinnship. To exemplify wrongdoing between status equals, we presented a story of a fight in which one of a paitr of 10-year-old twins attacks and harms the other; for that between actor and victim in a status authority relationship, an incident in which a mother harms her child while responding to a crying incident; for that between contractual equals, the selling of a defective car to a customer; and for that between those having a contractual authority t1e, an injury to a worker caused by an assembly Iine supervisor's disregard of safety precautions. Within each story four variables - mental state, consequences, past pattern, and other's Influence - were varied dichotomously.

$$
\begin{gathered}
\text { Insert Table } 1 \text { about here } \\
-
\end{gathered}
$$

Deed variables, contextual variables, and hypotheses. Below we discuss Initial predictions for the relationship of deed-related and contextual. variables to responstbility judgments. In the interest of brevity we present the experimental variations and hypotheses in relatively abstract terms. Full descriptions of all stories are available upon request.

Hypotheses 1-2. Since mental state is generally seen as a central element in adult responsibllity fudgments, we expected respondents to assign more responsibility to negligent acts than to accidental ones, and morc responsibility to intentional acts than to negligent ones. These three categories of acts correspond to the three Helderian levels that involve mental state: Commission, Foreseeability, and Intentionality. The dichotomous variations in our stories represented adfacent pairs among these levels. In contrast, the seriousness of an act's consequence should bear little relationship to adult responsibility judgments if we are to belleve the developmental 11terature (e.g., Plaget, 1965 (1932)). Yet an extensive soctal psychological 1iterature has explored the posstble impact of 
consequence severity on adult fudgments of accidents, with inconclusive results (e.g., see reviews by Fishbein and Ajzen, 1973; Vidmar and Crinklaw, 1974). We concluded that it was worthwhlle to examine the potential effect of consequence severity in a random sample of adults, using both accidental and non-accidental. occurrences. Any conclusion would be more defintive than could be the case with college subject pools and stimuli restricted to accidents. If an effect was found, we expected that higher consequence severity would increase attributed responsibility. ${ }^{11}$

Hypotheses 3-4. The first contextual varlable, past pattern of behavior, potentfally alters perceptions of the act commltted. It taps Kelley's $(1967,1.973)$ theoretical notions of consistency versus distinctiveness Information, such that past behavior can be efther consistent with a current bad act (suggesting causes internal to the actor) or inconsistent with a current. bad act (suggesting something distinctfve about the stimulus to which the actor responds). We anticipated, therefore, that bad past behavior would produce greater attributed responsibility than good past behavior. In addition, we expected that past behavior and current intent would interact with one another. For cxample, a bad past pattern might counteract Information about low intentionality in a current incident.

Hypothesis 5. The second contextual variable, influence from another person, provides an external cause for an actor's behavior when it 1s present. However, the 1mpact of this influence should vary depending upon the relationship of the actor to the other. For this mantpulation, we introduced another person influencing the actor in half of the versions; the other balf of the time influence was not mentioned. Note that this means there were potentialliy thrce parties to a deed--an actor, a victim, and another party influcucing the actor. For simplicity we made all relationships in a given story be of the same type. Thus if an actor-victim relationship was contractual and equal, so was the actor-other relationship. Th1s strategy also made it possible to view actors in authoritative stories as simultaneously superiors (vis-a-vis the victim) and subordinates (vis-a-vis the other). ${ }^{12}$ We predicted that initiative from a superior would reduce an actor's responsibility more than persuaston from an equal, and that any main effect of other's influence on responsibility would primarily reflect the influence of superiors.

Manipulation checks. These items were crucial for determining whether the experimental manipulations were in fact perceived by respondents as Intended. For checking the distinctions among mental state, two such items were needed for all storles, as the difference between accidental and negligent acts is not the same as that between negligent and purposive acts. One 11-point 1tem asked the extent to which the actor "d1dn't mean to" or did "on purpose" the act in question. A second dichotomous item asked whether the actor "could have avolded" the act or not. The first item f.s an intention check, the second a negligence check.

Since the mental state manipulation was always dichotomous, the appropriate manipulation check depended upon which levels of mental state were presented. When the 1ssue was accident versus negligence, we expected the "could have avolded" Item to be the appropriate manipulation check and the "on purpose" Item to show a relatively constant "didn't mean to" response. Conversely, when the 1ssue was negligence versus intent, we expected the "on purpose." Item to be the appropriate comparison and the "could have avoided" question to show a relatively constant "could" response. Thus the pattern of responses to these different items was expected to shed 1ight on different bases of responsibility at different levels of involvement of mental state. 
The manipulation checks for consequence severity and past pattern of behavior were more straightforward. The mantpulation of consequences used two levels of serfousness which pretests showed to he significantly different In each story; the manipulation was checked with an 11-point item going from $0=$ "not at all serious" to $10=$ "extremely sertous." Again using pretests to ensure appropriate variability, past betiavior relevant to the misdeed was described as either good or bad. That mantpulation was checked with a dichotomous item asking whether the actor's deed was or was not predictable based on the information given. ${ }^{13}$

The f lnal. manipulated varlable, influence from another, had no approprlate manipulation check given that influence was missing in half of the versions of ench story and present in the other half. We did, however, ask followup quest: fons about the relative responsibility of the actor and other 1n those verstons where influence was introduced.

Role effects: Informal predictions. Our basic argument is that roles, as normative contexts, should alter the impact of deed-related and contextual varlables on responsibility judgments. However, given the storles selected and the interaction effects anticipated, certain main effects of roles apppeared plausible in this data set. First, other things belng equal, one would expect a person in authority over a victim to be more responstble for wrongdoing than n person of equal status. We argue theoretically that superiors are held to strfeter moral. and legal. standards because authority carries with it greater oblifigations (see HamLiton, 1978) ${ }^{13 a}$. In contrast to ordinary actors, authorities may be hel.d responsible for events when intentionality is completely absent, as in vicarious and strict liability rules. They may also be held responsible according to more strict interpretations of a given set of rules. For example, standards of negligence may be more strict for authorities than they otherwise world be. Ln general; super Jors are being judged according to a combinat ion of mental state and diffuse role obligations and thus should be more responsible than equals for an action of anyrgiven degree of purposiveness.

In terms of the usual social psychological way of viewing responsibility Judgments, the Heiderian levels, this produces a methodological difficulty: The "same" mental state levels theoretically should not produce the same outcome in authoritative and equal relationships. Thus how one manipulates mental state becomes an 1ssue in comparing authorities and equals. Our original objective for the four core stories was to manipulate mental state between negligence and intentionality. However, pretests Indicated no appreciable variance in responsiblity in authoritative storfes unless we varfed mental state around lower levels. (As our model suggests, actors in supertor positions were invariably being assigned top levels of responsbility for intentional acts, while equal. actors were not.) Thus we settled on variations between carelessness and intentionality for the equal stories and between accidents with some carclessness versus clear indications of recklessness for the authority storles. ${ }^{14}$ Therefore, In order to control for differences in levels of mental state between stories, analyses involving formal and informal predictions about authority versus equality will use techniques deslgned to control for differences In percelved purposiveness of the acts depicted.

Moreover, as was noted in Hypothesis 5, authorftative actors were also described as being themselves under the influence of a superior in half of the stories. This intermediate position can confuse the impact of an actor's authority on responsibility. Thus we would expect any pure effect of authority versus equality to appear in vignettes where influence from another was absent.

It was also plausible to expect a status-contract effect because of the stories chosen. These stories were selected to represent as closely as possible the usual situations of wrongdoing in the relevant settings. 
In status relationships, we felt, it is often the case that the victim is In some way involved or Impltcated. This involvement can even follow simply from the presumption of extended interaction and generalized exchanges that characterize those relationships. The incidents we depicted followed this pattern. ${ }^{1.5}$ Thus less responsibility should be attributed to the actor in these status stories, since the victim's participation would reduce the actor's responsibility. Had we depicted completely unmotivated wrongdoing In such stories, however, we would have expected responstbility to be judged more severely in the status stories.

Thus the general model suggested a posstble effect for authority versus equality, witich in the present design would be partly masked by the presence of influence from another. We also: antictpated a possible effect for status versus contract because of the Implicit victim involvement in the status incidents.

The interactions of roles and deeds. We expected that the role dimensions would create normative contexts for the use of three kinds of information: mental state, past pattern of behavior, and fnfluence from another. ${ }^{16}$ Statist tcally, this normative effect would appear as interactions between the experimental varjables and the role typology.

Hypothesis 6. We hypothesized that the impact of mental state on responsibfiltity would be affected by both the solidarity and the hierarchy of the relationship. Concerning solidarity, status relationships are characterized by the parties' having greater knowlenge of each other's past and greater concern with the relationship's future. This should lead part.lcipants in such situations to take a more subjective orfentation to others' deeds, perceiving and using mental state information more. We belfeved that this tendency would be strong enough that even our respondents, reacting at best vicariously to the act, would weigh mental state more heavily in status than in contract stories because of their socfal knowledge of the content of such ties. The general hypothesis is that outside observers as well as participants judge deeds between those closely tied more subjectively than deeds between those more loosely tied.

Hypothesis 7-8. The 1mpact of authority on the use of mental state Information is theoretically more complex, both in general and in the specific examples used here. As was noted above, authorities are potentially held responsible at quite low levels of involvement of mental state because of their role obligations. Equals are not held responsible, or are held less responsible, because their wrongdoing is judged more heavily on the basis of their purposiveness or negligence. Th1s implies an interaction between mental state and hierarchy: Mental state information should have a greater Impact on responsibility for equals than for authorities. However, this prediction is confounded by the fact that information about mental state can potentially be used to assess the nature of a superior's unfulfilled role obligations as well as to assess mental involvement per se. ${ }^{17}$ Thus for superiors we hypothesize that mental state information may alter responsibility either Indirectly, by affecting judged purposiveness or avoldability, or directly, by affecting judgments of unmet ob1igations. For equals, in contrast, the only effect of mental state information should be through 1ts impact on mental state judgments; and, as hypothesized above, this direct effect should be larger than that for authorities.

Hypothesis 9. This model of an authority's responsibility as flowing from mental state information plus diffuse role obligations implies a final hypothesis regarding hierarchy. Differences between the responsibilities of an authority and an equal actor should be greatest at lower Heiderian levels of Involvement of mental state, where authorities are being held responsible toa substantially greater degree than are equals. The gap between authority and equal 
should he greatest, where association with an act or commission of that act are Involved. Given the presumed Importance of mental. state in adult responsibility fudgments, responsibilities of authority and equal should be more similar for neg11.gent acts. And as action becomes more clearly intentional, judgments should converge toward full responsfbillity for both authority and equa 1.

Hypothesis 10. As the discussion of solidarity and mental state suggests, status relations involve greater emphasis on and awareness of past patterns of behavior. We thus expected that variations in past pattern, 11ke varfations in mental state, would have greater impact in status than tri contract stories.

Ilypothesis 11. One obvilous expectation about the effect of role relations on other's Influence has al.ready been noted in Hypothesis 5: Influence from equal.s should reduce an actor's responsibilifty less than does influence from superiors. Cross-cutting this, however; is an expectation of somewhat greater subtlety. Because status relations involve an ongoing the of mutual obligation, one's superior in a status relationship should have less coercive control. Thus the impact of another's influence should be strongest in authority contract settings, weaker in authority status settings, and weakest in settings of equality between actor and another. Influence from nnother person should not have a unftary effect on an actor's responsibility for wrongdolng. The other person's role relation to the actor provides a key plece of taterpretive information.

In surunary, the model of responsibility norms as involving both roles and deeds suggested an empirical design to test for effects of deeds, effects of role dimensions themselves, and effects of interactions between roles and deeds. The interactions in particular represent the notion that roles serve as normative contexts, altering the Impact of variables previously studied in isolation.

\section{Data Analysis and Results}

Analys1s Procedures. The initial procedure for the core stories Involves a somewhat unusual analysis of variance. The design consists of four between-subjects factors (intent, consequence, past pattern, and other's influence) and two within-subjects factors (relationship hierarchy and solidarity), all varied dichotomously. Each respondent thus heard four sixty-fourths of a fully repeated design. Because higher-order interactions of the between-subjects factors are confounded with the within-subjects factors in such a design, we did not use a conventional mixed model anova. Instead, we first created an extended data file that treated each response as Independent. Second, we created four artificial between-subjects data sets by randomly selecting one answer from each respondent within the constraint that all four stories were assigned to one of the data sets. This produced four quasi-1ndependent replicat lons of the study as a fully between-subjects design. Then we analyzed each data set as a $2^{6}$ design and examined the coefficients for consistency across the four replications plus the extended file analysis. This procedure improves on that currently in use by Rossi and colleagues for experiments in surveys (e.g., Alves and Ross1, 1978; Nock and Ross1, 1978) because we were able to produce a discrete number of full replications of the design where they were not.

Since the experiment was conducted in the fleld and respondents given simple random assignment to conditions, cell $\underline{n}$ 's were slightly unequal. All analyses of variance reported actually used contrast coded dumny variable regression to produce a true least squares solution.

Manipulation checks. The relationships between the experimental variations and the manipulation check items serve to demonstrate that any absence of 
effect tn the data fis not a result of a falled mantpulation. In addition, we did not expect the mantpulat lons to affect fust "the1r var1able" and no other. The concepts involved-- purpostveness, sertousness, avoldability, and predictabilitey-- are not orthogonal concepts, though our manipulations of thetr corresponding experimental manipulations were. Explorations into how these items interrelate can suggest how the concepts are in fact 1inked by the respondents themselives. This Tahle 2 presents the relationships between each manipulation and all manipulation check items by story.

Inscrt Table 2 about here

Table 2 can be summarized simply in one sense: all manipulations worked. The effects of a given manipulation were always significant on the relevant manipuliation check, and in almost all cases those effects were substantially stronger than the effect of any other manipulation on that item. But as expected, the interrelationships prove interesting. The most important involve the two checks for mental. state and the relation of intention and past pattern. The intent manipulation significantly af fected purposiveness in all stortes, but affected avoldability only in the hierarchical stories. This pattern reflects respondents' strong tendency to say that the result was avoldable in the equal relationship stories, conf trming our priori assessment that those stories were constructed around higher average levels of the mental state varfable. Mental state and past pattern, in turn, are linked. $A$ bad past pattern of behavior always produced a higher rated purposiveness; higher manipulated intentionality also produced judgments that the deed was more predictable. (The latter effect was slgnificant only in the hierarchical stories, but the lack of significance in the other storles may reflect the higher overall. intentionality portrayed rather than any effect of role relationship per se.) Such results conform closely to common sense.
Previously "bad apples" are 11kely to be percelved as meaning to be rotten when they act badly again; and more intentional action 1s 11kely to be Interpreted as more predictable. Respondents appeared to Impose the sort of consistency on behavior that Kelley's $(1967,1973)$ attributional approach would predict. Overall, the results for the manipulation checks were both methodologically satisfying and suggestive of the ways in which the concepts may interrelate. These interrelations might provide hints for further research in the general area of causal attribution processes. ${ }^{18}$

\section{Overall analygis of variance of responsibility attribution. Results} for the overall analysis and the four quasi-independent replications are presented in Table 3. For the extended file analysis, the $E$ tests, significance levelels, and unstandardized coefficients are reported for all results significant at the conventional $\mathrm{pm} .05$ level in the saturated model..$^{19}$ For the replications, the corresponding coefficlents are presented. All coefficlents are contrast coded to reflect the difference between the mean and the "high" cells. They should be doubled to obtain the difference between high and low cells on the $11-p o i n t ~ s c a l e$ for the dependent variable.

Insert Table 3 about here

Since the question of the true effect of roles on responsibility requires some special accounting for the issue of differences in purposiveness, we turn first to a sumary of the main effects of the deed-related and contextual variables. All results are straightforward. Mental state had a powerful main effect on responsibility assigned, as suggested by Hypothesis 1 as well as all psychological and legal theories. Greater intenttonality produced greater responsibility. Seriousness of consequences had a small effect on responsibility fudgments, but the effect is unstable across replications. The direction of this unstable effect, as expected in Hypothesis 2, is that more 
severe consequences produced higher responsihilltty. Past pattern of bad versus good behavior had a slzeable effect on responsibility, with bad past bchavior leading to greater responsibility as predicted in Hypothesis 3 . Flnally, influence from another had a small but stable main effect on responstibtlity, such that the actor was less responstble when under influence from another. As noted in Hypothesis 5 , we expected this main effect to be sma1.1. if it existed at al1, given predicted differences between equal and suthoritative influence.

Table 3 also shows what appear to be dramatic effects of both role dimenstions. These main effects indicate more responsibility assignment in coritract than in status situations and more in equal than in autlioritative situations. Taken together, these apparent effects are more than double the effect of manipulated mental. state. However, as Indicated above, examining effects of role dimenstons requires taking account of hoth the presence versus absence of another's influence and the differential Intentionality in, the stories presented. Figure 1 presents path models predicting to responsiblitity with other's influence present versus other's influence absent. The path models include the exogenous varlables mental statc, hlerarcly, and sol.1dartty; and the endogenous variables "on purpose" and "avotdabillty" ns control.s for percetved mental tnvolvement of the actor. ${ }^{19 a}$ "This contrul strategy is a conservative one, as th removes from the direct effects of roles any aspect of "rotes themselves" thiat lead to differences in inferred mental. state as wall. as removing confounding due to different mental state man.lpulations. The model.s exclude the interaction between role dimensions bccause fit was unstable across the quasi-independent replications. Models were run in the extended file as well as in the replication flles. For simplicity, the range of path coefficients from the replfications ts summarized in parentheses below the coefficlents for the overall. anal.ysis.
Insert Figure 1 about here

Figure la shows that solidarity continued to have a sizeable and stable direct effect on responsibility when other's influence was absent. As in the Initial analysis, more responsibility was assigned in contract situations than In status situations, confirming our informal expectations. Hierarchy had a smaller and less stable direct effect, but in the generally expected direction: Authorities were more responsible than equal actors with purposiveness controlled and influence from another on the actor eliminated.

As expected, Figure 1b 11lustrates that influence from another serves to muddy the waters of both role effecta. The status-contract direct effect, though still significant, was reduced. As we shall see below, this results from the predicted Impact of other's influence, which reduces responsibility more in contract stories than in status stories. And the aurhority-equal effect was reversed: the introduction of other's influence depressed the responsibility of authorities slightly below that of equals. Thus the authority who 1s also a subordinate loses the responsibility edge that our model suggested and our data confirmed in Figure $1 \mathrm{a} .^{20}$

The overall Impact of the role vartations thus proves to be slzeable and consistent with general expectations. Size comparisons with direct or Indirect effect of mental state on responsibility are unwartanted, however, for a number of conflicting reasons. First, mental state was not itself varied across all the possible Helderian levels, but only dichotomously in any given story. Second, the strategy of controlling for perceived mental state is, as noted above, a conservat fue one that may remove an unknown component of "true" mental state difference produced by roles themselves: Finally, as suggested in liypothesis 8 , the direct path from mental state to responsibility is an inappropriate indicator of mental state per se. 
Interaction effects. We had predicted interactions between mental state and past pattern, solidarity, and hterarchy; between past pattern and solidarity; and between other's influence and both role dimensions. As the overall annlysts in Table 3 Indicates; only some of these expectations were confirmed. We shall discuss the results in order of the theoretical importance of the 1ssues, treating the mental state-role interactions first, followed by the other's influcnce-role interactlons, and concluding with the past pattern i.nt:eractions.

In llypothesis: 6 we argued that mental state should prove more important II status relationships than in contract ones. Although there was no significant interaction between mental. state and solidarity, there was a small three-way tuteraction of mental state, solidartity, and consequences. This interaction, which was of modest magnitude and relatively unstable across replications, is presented in Table 4: Tests for the mental state-solidarity interaction show that when consequences were severe, variation in mental state had a significantly greater effect. on responstbility in status stortes. Th1s relationship, which is consistent with the original hypothesis, did not hold when consequences are mild. The data thus i.mply that when things turn out badly and people search for an explanation, they nre more likely to turn to mental state information in status relationships. The relationship, however, is much weaker than we had predicted.

Insert Table 4 about here

The predicted relationshtps of mental state and hierarchy were more complex. Table 5 presents the means for both responsibility and purposiveness fudgments by levels of mental state and hierarchy. Looking first at responsibility alone, Table 5 explains the signif icant mental state-hierarchy interaction from Table 3. Changes from low to high levels of manipulated mental state made more difference in authoritative than equal relations. The corresponding purposiveness ratings indicate that this responsibility difference occurred in the face of an opposite pattern for judged purposiveness. Differences in purposiveness from low to high levels of mental state were signif Icantly smaller for the authoritative stories. (From a separate analysis of variance on purposiveness, F $(1,2605)$ for the interaction=4.39, $\mathrm{p}^{\mathrm{0} .04}$.) These results Indicate that respondents were quite attentive to small differences in mental state when they occurred for authorities, more attentive than for larger changes when the actor and victim were equals, in apparent contradiction to Hypothesis 7 .

Insert Table 5 about here

Hypothesis 8 suggested, however, that mental state Information can have two uses. It can directly affect judgments of an actor's mental involvement, but it can also be relevant to assessing an actor's obligations. Figure 2 therefore presents the path models for the direct and indirect effects of mental state separately for authoritles and equals. (Results are collapsed across the other's influence variable because it did not significantly alter the patterns shown) The figure indicates clearly that for equal actors, mental state information was information about purposiveness or avoldability; and mental state had a powerful effect on responsibility through its effect on these variables. The Indirect effects of mental state were simflar for authorittes, contrary to Hypothesis 7 . But there was also a significant direct path from mental state to responsibility for authorities, a path that we interpret in terms of authoritfes' obligations of attention and foresight. Thus Hypothesis 8 is confirmed, in that use of mental state information in judging authorities 1s something "more" than previous psychological models suggest.

We argue that the "more" reflects the diffuse obligations of the authority's role. 
Insert Figure 2 about here

Hypothesis 9 argued that the differences between authorities and other actors are at their maximum at low level.s of involvement of mental state, and that the responstbilities of authorities and equals tend to converge when action 1.s fully intentiona1. Givell the differences in our manipulations of mental. state for authorities and equil.s, an adequate test of this hypothesjs must use respondents' own perceptions of how purposive the actions wcre. Thus Table 6 shows the effects of hierarchy and mental state on responsibilitity stratified by levels of perceived purposiveness. Judged purposiveness was divided for conventence into categories labeled here as accidental, careless, and Intentional acts. Results are presented separately for conditions where other's influence was absent and present to clarify interpretations.

Insert Table 6 about here

Results for the conditions with other's fnfluence absent clearly show the predicted pattern. When an action was fudged as accidental, authorities were sigulff tcantly more responstble than equals. In addition, the now-familiar Interaction appeared such that change in level of mental state had a stgnif ticant effect for authorittes, but not for equals, with perceived purposiveness controlled. When the action was judged as careless, authorities wcre again st.gnifficantily more responsible than equals. The interaction, though st11.1. visually evident, was no longer significant. Finally, when action was Judged as intentional, no differences were signtficant -- judgments of authortitics and equals had converged.

Fven with the confounding presence of influence from another party, the right side of Table 6 shows the same finteraction of hferarchy and mental state for acts judged as either accidental or careless. Remaining significant effects of mental state itself in these subtables are functions of the Interactions. Although the main effects of hierarchy itself are neutralized or reversed by the presence of another's influence (as Figure 1 had already demonstrated), two points are striking. First, the interactions remain. Second, the models for authorities and equals again converge in the subtable for action perceived as intentional. Thus H.ypothesis 9 is clearly confirmed. The normative models of responsibility for authorities and equals converge to linear "main effects" only when purposive action is involved.

As the discussion of results so far has already anticipated, the interaction of other's influence with hierarchy was substantial and consistent with Hypothesis 5. The means for the significant interaction, first shown In Table 3, are presented in Table 7. Influence from another had a greater impact on responsibility in authoritative settings (where the other was an authority) than in equal settings (where the other was an equal). In addition, Hypothesis 11 suggested that the impact of authority should be particularly strong in contract settings. Although the contract-status difference was not large enough to produce a significant three-way interaction, results were indeed consistent with the hypothesis. The impact of another's influence was only marginally stgnif icant tn the status story $\left(.10<\mathrm{p}^{<.05}\right)$, while it was highly significant in the contract story $(p<.001)$. Thus influence from another proved to have finely differentlated effect on an actor's responsibility, as predicted, depending on the type of role relationship involved.

Insert Table 7 about here

The final predicted interactions involved past pattern of behavior.

Hypothesis 10, which had argued for an interaction between past pattern and solidarity of the role relationship, was simply disconf irmed. Hypothesis 4 , 
which argued that past pattern and mental. state shoul.d interact, received some indirect support. Al.though there was ṇo significant interaction in the overall. analyses of responsibflity, it is noteworthy that the results for manipulation checks presented in Table 2 did show effects of past pattern on percetved purposiveness. This suggested a link between those concepts in the eyes of respondents. Inspired by the analyses in Figure 2 (where authoritics and equals differed in the direct effect of mental state on responsthilitity), we therefore conducted parallel path models for the direct and Ind trect effects of past pattern on responsibfilty with purposiveness and avotiablitity controllied. We agatn collapsed across other's influence beacuse fit did not alter the pattern of results. The outcome, summarized in Figure 3, 1.s linstructive. For equal actors, there was no effect of a past pattcrn of bchavior on responsibility other than through its effect on perceived mental. state. For authorities, in contrast, there was a significant direct effect of past pattern on responstbilitity. These results again indicate that the normative models of responsibility for authorities and equals are different. For authorittes, a past pattern of behavior 1s something other than a clue to the mental state of the actor; for equals, it is not.

\section{Insert Figure 3 about here}

Summary of basic results. The findings so far have generally supported the proposed model of how adults fudge responstbility for wrongdoing. ${ }^{21}$ It is a matter of more than those varfables, intent and consequences, so long studicd by psychologists. Responsibility is instead a matter of role expectations as well as phystcal actions. The role relations introduced into our vignettes produced both slzeable main effects on responsibility fudgments and theoretically important and stzeable fnteractions with traditional decd-related variables. Netther an actor's mental. state, nor the actor's past pattern of behavior, nor the possible presence of influence from a third party, can be considered as determinants of responsibility in isolation from the kInd of role relationship involved. In general, the most striking findings concerned the normative structure of wrongdoing for authorfties versus equals. The judgment of responsibility for authorities was different in ways consistent with predictions based on those authorities' role obligations.

\section{Subsidiary Results and Threats to Inference}

Despite the general confirmation of the model of responsibility judgments, two subsidiary analyses and one major threat to validity remain to be addressed. A first subsidiary analysis concerns the other stortes presented to respondents, the more traditional auto accidents and crime story. The standard variables of mental state and consequences were also manipulated there, and the psychologist interested in salvaging consequence severity as an issue in responsibility might wonder whether situations where no prior roles are Involved are the approprlate "home" for the study of consequences. A second subsidiary analysis, in 1ight of the Importance of authority-equal differences observed, concerns the responsibility of the third party who inf luenced the actor. If authorities and equals in fact differ in the ways we have suggested, then results for the other's responsibility are a fascinating part of the puzzle, given that the third parties were themselves either authorities or equals. Finally, the major threat to valid inference concerns the 1 imitation of the main interview to single stories of each role type. This 1imitation is most Important where predictions Involved differences between Individual stories, as they did for other's influence; it is less important where predictions Involved pairs of storles versus other pairs, as was otherwise always the case. Below we shall present results from a story included in the mallback questionnatre that varfed role relations between actor and other in a single setting, providing ? a stringent test for the validity of our conclusions about other's influence. 
Other stories presented. As was noted earlier, the crime story Included vartations in the actor's mental state, the act's consequences, and the actor's past pattern of behavlor. Two auto accidents were presented: In one, the three vartables of mental state, consequences, and past pattern were varted; in the other, the actor's soctal status replaced past pattern. For present purposes, the results from these vignettes can be presented in bri.ef verhal summary. Mental state had a stgnificant effect on responstbility in both auto acctdents. Past pattern, where it was tncluded, also affected responsibility, but more weakly than mental state. The actor's soctal status had io effects except for interactions with mental state and consequences that turned ont to be complex and dependent on the respondent's sex. Consequence severfty per se affected responstbility in neither story. In the crime story, somewhat surprisingly, only past pattern (presence or absence of a prior record) affected responst.blitity at all. The lack of results for mental state may perhaps be attributed to a celling effect; g.tven that most respondents rated the criminal as fully responsible for the deed. The overall pattern of results across these stories, then, virtually mirrors the results for the stories involving role relations. In the absence of role relations, as in their presence, mental state is the most important element of deeds, followed by the actor's past pattern of behavior. Consequence severfty is of negligible Importance 1rrespective of the setting.

Responsibility of the Influencing other. Two follow-up questions asked about the responstbility of the other when other's influence was present. We first asked respondents whether the other person had any responsibility for what happened; and If so, whether it was less than the actor's, equal, more than the actor's, or all of the responstbility involved. We then constructed a composite variable ranging from one (none) to five (a11), for the responstbillity of the other person relative to the actor. Analyses of variance were then conducted on this variable using the remaining $2^{5}$ saturated model (omitting other's influence and its interactions, of course, because the 1 tem was only asked when influence was present), The results for the only significant and stable effects are presented in Table 8 .

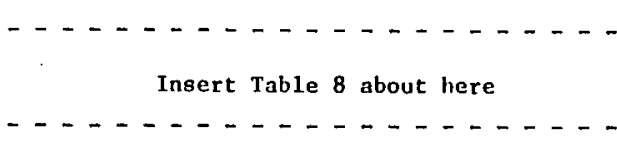

There were two clearly observable maln effects of role relations on the other's responsibility. Others who were in contract relations were more responsible than others in status relations, and others who were authorfttes were substantially more responsible than others who were equals. These results are mirrors of the previously noted effects of other's influence on the actor Involved. The four means also lined up in perfect theoretical order, with responsibility for a status equal lowest, followed by responsiblitity for a contract equal, followed by a status authority, and with top responsibility for a contract authority. The gaps between these means were unequal, however, producing a significant interaction effect as well.

The absence of any effect of the actor's own mental state 18 particularly striking given its role in the maln analyses. It would seem plaustble that an actor who meant to perform a misdeed would retain more responsibility even if that misdeed was initiated by another. Respondents' reactions are congruent, however, with a major theory of the role of causaition in the law that derives from philosophical ordinary language analysis (Hart and Honore, 1959). According to that approach, humans tend to push causal chains back to a voluntary human actor who initiates a deed. These results simply confirm that in pushing back the causal cha1n, orders from a supertor are more clearly initlatory than persuasion from an equal; and Influence from someone socfally distant is more clearly inftiatory than influence from another who is close to the actor. The questions respondents were answering 
here were about the starting point of the causal chain, and therefore the actor's own mental involvenent was indeed Irrelevant.

Such results are suggestive of a deeper conceptual point about responsibility fudgments. It ls quite plaustble for an actor to be "fully responsible" at the same time that another party influencing the actor ts more responsible for what happened. The first question deals with the 1fability of a person for sanctlons: the second, with the relative 1labilfty of another for potentfally greater sanctions. Here the pattern of results for the actor's responsibility, coupled with those for the Influencing other's responstbility, suggests that respondents were implicitly using a "200\%" rule rather than a "100\%" rule in conceptualizing responsibility t.tself. Given the uhiquitous presence of human causal chains in modern hureaucratic states, the question of how humans fudge absolute versus relative responsthillty for wrongdolng is clearly one worthy of further investigation.

\section{Meeting the threat to inference: Role relations in a single story. Although} thme pressures prevented our using more than six vignettes in the main instrument, we were sensltt.ve to the possible claim that some results reflected idlosyncratic clements in the storfes chosen rather than "true" effects of relationships. The most vulnerable result concerned the different effects of authoritative third parties in status and contract relations, both because the prediction involved comparing Isolated storfes and because the status authorfty in the main instrument was a hushand (who some observers might plausibly feel was not an authority over a wife; sec footnote 12 ). Therefore we included one story in the mallback instrument in which role relations between actor and other were varied in a single setting. Since the matllhack was returned hy only about half of the survey respondents, we cannot make the snme clalms to generallizability that are avallable for the core stories. ${ }^{22}$ llowever, given that the matilback sample is still1. considerably more representative of an adult poptiation than is characteristic of related psychological research, we felt that the additional vignette could provide key support -- or disconfirmation -- for the theoretical arguments.

The vignette involved a man who infected some infants in a hospital where he worked by staying on the job while 111. The experimental manipulations included the actor's mental state plus three variables related to another's influence. These variables were the other's hierarchy (coworker or supervisor), solidarity (was a friend/friendship not mentioned), and exertion of control (suggested/got angry and told the actor to stay on the fob). Note that solidarity is quite a weak manipulation in this story, such that if its results replicated those from the main design we would be quite confident that no Idfosyncractic interpretations had produced the Initial results.

Table 9 presents the significant results from a $2^{4}$ analysis of varlance for responsibility assigned to the actor. Three of the four maln effects were significant. Although mental state had no apprectable effect, an examination of the manipulation checks revealed no signiffcant differences between conditions, indicating that mental state was not successfully manipulated in the story. Thus the faflure of mental state to affect responsibility does not contradict carlier findings about the Importance of that varlable. A11 other main effects were as experted. The actor was less responsible when the other person was a supervisor, when the other person was not a friend, and when the other person got angry rather than suggested that he stay. We expected influence from an authoritative other to reduce responsibility more because the role relations turn even a suggestion into a directive. Simllarly, we expected that in a friendship (1.e., status) relation the worker would have more countervalling influence on the other, and hence retain more responsibt1Ity, than in the absence of friendship. Finally, the exertion of angry control by another more clearly provides an external cause for the behavior, a voluntary human further back in the causal chain. 


$$
\begin{array}{r}
-\ldots \ldots \\
\text { Insert Table } 9 \text { about here, }
\end{array}
$$

As Table 9 Indicates, there were also significant interaction effects between hifcrarchy and control and between hiterarchy and solidarity. The means for these interactions appear in Table 10a and $10 \mathrm{~b}$. From the first interaction we see that the control. excrted by the other made 1ittle difference in an equal relationship, but more difference in an authoritative one. This is consistent with the general pattern that influence from an equal is simply discounted in attributing responsiblility, however that influence fis clothed. It adds to our picture of authority the point that strongly worded directives have more 1mpact, presumably because they morc clearly remove causal agency from the actor. The second interaction shows that the presence of solfdartty made essentially no difference in equal relations, but has a large effect in authoritative relations. An authority who was also a friend had substantfally less impact on an actor's responsibility. This interaction replicates within a single vignette the pattern found th the main instrument for authorities across status and contract stories, and lends confldence that the result from the matn instrument is indeed a result of the role relations themselves rather than t.dlosyncratic elements.

$$
\text { Insert Table } 10 \text { about here. }
$$

Given the failure of the mental state manipulation in this vignette we were unable to examine the mental state-role interactions found in the main analyses. We did find, however, that the hilerarchy variahle (supervisor versus coworker) had a signlficant effect on the "on purpose" mant.pulation check $\left(\mathrm{r}=.43, \mathrm{p}^{<.0001)}\right.$. The actor was seen as acting less purposively when Influenced by a boss than by a coworker. $\Lambda$ s the "on purpose" vartable in turn cocrelated with responsibility judgments In thils story, Influence from authority partily affected responsibility through altering the percelved mental state of the actor. Yet the Impact of authority was not solely due to its effect on purposiveness. A path model including all three role-related vartables as exogenous varlables, purposiveness as endogenous, and responsibility as the dependent variable, showed that the effects of all three exogenous variables were essentlally unchanged and still significant as direct paths. This result suggests that influence from an authority has two effects: it alters responsibility by modifying perceptions of the actor's mental state, but it also affects responsibility by reducing the actor's role obligation to avold misdeeds. Thus the authority-actor link here shows intruiging parallels with results for the authority-victim link In the main anlysis. In both cases the responsibility that devolves on the actor is a function of both perceived mental state and role obligations themselves.

\section{Conclusions and Suggestions for Further Research}

Psychologists since Jean Plaget have had what is clatmed to be a universal model for the human judgment of wrongdoing. Yet that model ignores the soctal setting of action in favor of focus on the deed itself-- in particular, on the actor's intent and the act's consequences. From a sociological viewpoint, it is clear that responsibility for wrongdoing should be a function of the social expectations held for the actor as well as the deed performed. These soctal. expectations include generalized norms for behavior, particulartatic considerations arising in any given situation, and socially differentiated expectations: social roles. We have argued that language, law, and sociological theory each Incorporate two fundamental dimensions of soctal roles that may govern respons1bility fudgments. These dimenstions are the hierarchy of the relationship - 
whether it t.s between equals or an authority and subordinate - and the solidarity of the relationship - whether th ts between those bonded by a solidary status or linked by an implicit or explficit contract. The present paper constituted a first empirical examination of whether roles as well as deeds are crucial to understanding human responsibility fudgments.

The data set, a random sample of the Detroit S.M.S.A., Included responses to experfimentall1.y varied vignettes about wrongdoing in everyday $11 \mathrm{fe}$, as well as the more formal. legal. situations of auto accidents and crime. We included variations in the deed performed, the tradittonal psychological variables of actor's mental. state and act's consequences; variations in contextual aspects of the decl, the actor's past pattern of behavtor and the presence of influence from nother party; and varfations in the two role ditmensions of hierarchy and solidartity. Must of our expectations about the effects of deed-related variat.lons, of role dtmensfons, and the interactions of the two were confirmed.

The way deeds affect fudgments of wrongdoing appears clear-cut in the present data. Mental state of the actor was a crittcally 1mportant determinant of responstbjlity. The actor's past pattern of behavtor was a substantial, but less important, determinant. As prior developmental data suggested, severity of an action's consequences had a trivial. effect on responsibility judgments in our role-relinted stortes, and no effect on fudging either auto accidenta or crime vignettes. Finally, influence from another person on the actor had a small overall effect on the actor's responsibility. As we predicted, however, the meaning and tmpact of influence from another depended on the role relationships between the partics tnvolved.

We argue that roles are theoretically normative contexts for interpreting actions. But they may have direct tmpact on judgments of responsibility, as well as alterling the meaning or use of deed-related information. We found main effects of both role dimensions, such that authoritles were held more responstble than equals and persons in contractual relations to their victims more responsible than those in status relations. The effect of solidarity on responsiblity was particularly potent, but we belfeve that it is due to our attempt to present "typical" Instances of wrongdolng in the role relationships involved. The victims in our status relationship vignettes were to some extent implicated in the onset of the actor's deed, as 18 probably typlcal of wrongdoing between those closely tied. Child abusers, wife abusers, bullies, and the like of ten have excuses that involve the victim's deeds. Completely unmotivated or unprovoked wrongdolng in solidary relationships, in contrast, would probably evoke more severe responstblity fudgments and sanctions than those meted out to actors in contractual relations. Thus the "main effects" of role ties on judgments of wrongdoing are still at 1ssue. Further examination of norms about wrongdoing in status relations is especially important.

We expected both role dimensions to interact with deed-rclated varlables in determining responsibility. We were disappointed in the results for the solidarity dimension. Only weak evidence emerged that the kind of tie between participants affected use of deed-related Information, although that evidence involved the theoretically crucial variable of the actor's mental state. Hierarchy, however, altered the impact of all the important deed-related variables. The data support our arguments that authorities and equals are not judged by the same normative model of responsibility for wrongdoing. Being an authority creates a set of heightened expectations about one's behavior and thus establishes obligations over and above the general social obligations not to act carelessly nor to intentionally cause harm.

This set of heightened expectations for authorities had several effects in the present data. First, authorities were more responsible than equals for actions of a given degree of purposiveness. Second, mental state information had a 
grcater fmpact on judgments of authorittes than on judgments of equals. This effect, however, must be understood in 11.ght of the complex normative role of mental. state information f.n evaluating authorities. Mental state's 1mpact on the responstbility of equal actors can be understood simply as imparting information about the actor's purpose and the deed's avoldability. Its effect is entirel.y deed-rclated. But for authortities, mental state information affects responsibility hoth hy altering perceptions of purposiveness or avoidability and by dircctiy affecting the actor's responstblitity. We interpret this direct effect as evidence that autlorities have diffuse role obligations that Include obligations to be attentive to the situation and to safeguard the welfare of subordinates. Fulfilliment of such obligations is measured in part by the authority's mental state when the deed occurred. Third, these obligations involve l.css than I.ntentional action. Where actions were fudged as purposive the

- normative models for authorittes and equals converged to one based on purpostveness alone.

Al actor's past pattern of behavior, like his or her mental state, represented a clue to a deed's purposiveness or avoldability when respondents fudged equal actors. For authorities, past pattern had an effect on responsiblity over and ahove f.ts impact through the purposiveness and avofdability variables. We ng,aln infer that this reflects the authorfty's role obligations, and a bad past pattern of bchavior sensitizes observers that obligations have not been met.

Finallity, finfluence from another person had no tmpact on the responsibility of equal actors. It had a large impact for authorities in contractual relations and a smaller one for authorfitics in status relations, as we had predicted.

Given the importance of chiains of command in bureaucratic, political, and military liferarchies, further exploration of how the responstbility of authorities is dimlntshed by the intervention of "higher ups" is a key area for further study.
Suggestions for further research. Several important steps remain undone in the present work. For reasons of brevity, we have concentrated on fudgments of responsibility for wrongdoing. But the sanctions that respondents wished to employ are another aspect of how humans assess wrongdolng; a paper on that topic is in preparation. We have also spoken of "humans" and of "norms" as if the humans are undifferentiated and the norms universal. Yet as any sociologist or anthropologist would reply, perhaps the normative structure of wrongdoing is different for some demograpic groups or for some other cultures. Within this society, it is important to explore possible differences between male and female judgments of wrongdoing, for recent psychological research suggests that the "male model" reflected In some current theories may not apply to females (e.g., G111igan, 1978; Hoffman, 1975; Sampson, 1978). It appears equally important to search for soctal class or race differences, given evidence that divergent socfalization practices across classes and races lead to different models of morality (e.g., Kerckhof $f, 1973$; Kohn, 1969). In the present paper we wished to ask whether there was any benefit to be obtained from a roles-and-deeds model of judging wrongdoing; in a future paper, we will ask whether all parts of that model hold across important soctal categorles.

A final barrier is culture itself. We have explored fudgments of wrongdoing in a country that is fdeologically individualistic with regard to wrongdoing. To find effects of role relations on responsibility in such a culture is to find them in a place where the deck is probably stacked in favor of deedrelated or contextual variables. We argue generally that knowledge of roles and knowledge of deeds are both cructal to judging wrongdoing in all cultures, though cultures may differentially emphasize either actors' deeds or their role obligations. Thus we have collaborated with a group of Japanese scholars to replifate 
the basl.c Detrott study in Yoknhama and Kanazawa, Japan. ${ }^{23}$ Reports on those data sets willt also he forthcoming; we expect them to show greater emphasis on role relations as normative principles in more obligation-oriented Japan.

Beyond these ongoing efforts, a variety of research opportunities are availabl.c to soctal. scientists interested in a more comprehensive model of how humans judge wrongdoling. Nethodologically, we and others should move beyond the limited st.fmulif presented tin this study, to find out whether other role relationships that muglte to yteld the same resulits actually do so. Investigating roles that are Internediate on efther the hierarclyy or solldartity dimension is a further step. Conceptually, exploring the tenstons in solidary relations where the victim is not implifated and exploring in depth how humans judge wrongdoing in chintins of authortty are Important tasks to whicl we have already alluded. What we hope to have shown is that no model of how humans fudge wrongdoing can be complete without constdering role expectations and their effects. But we have begun, not: ended, the investigation of those effects.

Broader Implifcations. If, as t.t now appears, role expectations play a fundamenta1. part in the fudgment of wrongdof.ng, they may also have practical finpl.tcations for sanctioning practices. Most obviously, many aspects of the 1.cgal. procesis, from fury trials to legfslative and administrative rule making, may be influenced by fuller consideration of role expectations. Our culture's Interpretfve tdeology of wrongdoing usuatly rests on what we have called deedrelinted or contextual factors. Thus the legal model has basically assumed a "normal situation" which is contractual and equal. Yet results Indicate that this "mormal sttuation" is not uniformly transferrable to other role relationships. The presence of hierarchy and the presence of status ties fundamentally al.ter responsibilifty fudgments.
A11 of us are generally aware of this problem, as when we feel that the law does a poor job of settling domestic disputes, or when we feel that bureaucratic rules fall to pin responsibility on anyone. But it is important to move beyond this general sense of unease to work toward a deeper understanding of how rules and legal institutions function (or should function) when conf ronting different role relationships.

Finally, at a more theoretical level, studying the impact of roles on fudgments of wrongdoing should provide a better understanding of roles themselves. A role 1s, ultimately, a set of expectations based upon certain obligations. To study the process of holding individuals to account when obligations are breached 1s to study roles, role boundaries, and the ways in which they mesh to form the horizontal and vertical web of society itself. 
FOOTNOTES

1. In The Moral Judgment of the Child, Ptaget argued that chlldren shift from cmphasis on the objective consequences of action as a determinant of its wrongfulness to emphasis on the actor's subjective intent. Within psychology, moral development has become an area rich, in research and controversy since P1.nget (see, e.g., Koh1.berg, 1.969; Lickona, 1.976). For present purposes, however, the Importance of Plaget's contribution ts that it centered theorizing about responstbflity around the hoped-for universals of judgments of actors' intention and actions' consequences. Research following from Heider's (1958) claboration upon plaget has emphasized exther the development of responsibility fudgments in children (e.g., Shaw and Sul.zer, 1964; Harr1s, 1977; Fincham and Jaspars, forthcom.ing) or adult judgments of responsibility for accidents, with primary concern for the effect of severity of consequences (e.g., Walster, 1966; Shaver, 1970; Akkelin, Oakley, and Mynat.t, 1979).

2. Other recent critlques have begun to address the issues of whether there is a single cont Inum tnvolved and whether there is even a single underlying concept of responsibility (e.g., Fishbein and Ajzen, 1973; Vidmar and Crinklaw, 1.974; Harvey and Rule, 1978). Yet these critiques, save that of llarvey and Rul.e, lave still. focused on responsibility as arising from the deeds comnittted by an actor. Harvey and Rule have begun to argue that resnonstbflifty i.s a matter of "oughts" as well. as actions in a manner similar to llamL1.ton (1978); but thcy have not addressed the 1ssue of whether "oughts" are socfal.jy differentlated by role post.tions or other factors.

3. In dfscussing the dimenstion that we are callifing hierarchy, Brown actually uses the term status. What he means by status, however, is clearly authorityequality-subordination; and we prefer to reserve the term status for a different dist Inction discussed below.
4. Th1s is not to suggest that Japanese axe Insensitive to the issue of solidarity, but merely to emphasize that their language is rich in terms for hierarchy. As an example of their use of solidarity information, the Japanese use four verbs that translate into the English verb "to give." These four verbs reflect both the hierarchy of the relationship between giver and receiver and their personal closeness or distance. Gift giving is an extremely important aspect of Japanese social relations.

5. For example, strict liability standards have been adopted against employers In the area of workman's injurtes and against manufacturers and retallers in the area of llability for products that contain defects. In general, the civil duty people have to each other is in part determined by the power and/or authority they have over each other (see Green, 1930). As Marsha11 Shapo notes in a recent work, "analysis based on power provides a most satisfactory framework for tort questions of duty, .." (1977:x111). For him power means different ways in which people exercise control of others' destiny in particular transactions or circumstances.

6. A recent sociological controversy has concerned potential differences between criminal of fenses among assoclates versus strangers (e.g., Black, 1976, 1979; Gottfredson and Hindelang, 1979, a,b). Both sides of the controversy agree, however, that legal processing of offenses within the bounds of family or friendship may not occur because participants themselves do not see it as a matter for the law.

7. To cite a qualnt version of this legal concern, the fudge in the old case of Ritter v. Ritter (31 Pa. 396 (1958)) argued: "The flames which litigation would kindle on the domestic hearth would consume in an instant the conjugal bond, and bring on a new era indeed -- an era of universal discord, of unchastity, of bastardy, of dissoluteness, of violence, cruelty, and murders." More recent cases involving intra-family torts have adopted a much more open 
posture, often on the theory that serfous torts themselves effectively dissolve the conjugal bond, and thus there is nothing left for the legal process to destroy.

8. We should emphastze that we concefve of both hierarchy and solidarity as dimenstons rather than dichotomies; we are simply examining idea1-typical extremes in the present study in order to determine the usefulness of the dimensions. A number of soctal relations would obviously be internediate between the ones we have looked at on one or both dimenstons. The teacher-student tie, for example, is probably intermediate in solidarity throughout the $1.1 \mathrm{fe}$ cycle and changes in its rigidity of hierarchy with the student's age.

The overall typology that results is most closely stmilar to the distinctions made by Peter B1au (1964) In Exchange and Power in Socla1 Life. B.au distinguished between situations of intrinsic versus extrinslc exchange and between reciprocal versus unflateral transactions. In speaking of hierarchy and ties instead of power and exchange, we hope to subsume Blau's distinctions and add a slightly different emphasis.

- Obviously, a hiferarchy of authority versus a situation of equality is s.tmilar to what Blau called power versus exchange. Further, what we call a contract relationship is 11kely to be characterized by extrinsic exchange, in which parties see each other as means toward ends. A status relationship is 1ikely to be characterized by intrinstc exchange, in which the parties volue the exchange itself. Dyadic exchange may be aptly characterized by Blau's labels. Responsibflity, however, is a different story. The allocation of responsibility fundamentaliy rests on the existence of third partics: other people whose explicit or implicit expectations help to define the obligations of the actors. For example, to be an authority you need a sutordtnate-- but you also need some other person or persons who define you as the authority, if only to enforce sanctions when called for. Thus Blau's distinctions embody much of the social psychological content of the relations we are considering. The distinctions we suggest here are an attempt to better capture the social enforcement of responsibility.

9. We also split the interview time of the D.A.S. with another project concerned with attitude-behavior consistency. Their part, approximately 20 minutes' worth of material on television watching preferences, preceded our own. Although a few of their items dealt with "police and crime" shows, and one Item asked whether there was too much violence on T.V., we seriously doubt that these questions would have any sensitiztng effect, given thiat they were enbedded in a total of 49 items related to T.V. Further, any such effect would presumably be strongest for the initial story heard, and our Latin Square design ensured that each story would be heard first an approximately equal number of times.

10. In neither the crime nor the accident did we vary other's Influence, as that would represent only the theoretically less interesting case of coercion. In the crime story, therefore, we varied mental state, consequences, and past pattern of behavior. Two auto accidents were actually used, alternated In the computer generation of questionnaires so that $\underline{n}$ 's for the two were approximately equal. One accident examined the standard variables of mental state, consequences, and past pattern. In the other acc1dent, we replaced past pattern with variation in the social status of the actor. This was done in part because the basic design was to be replicated by a group of Japanese colleagues on a Yokohama area sample, and both research groups were Interested in exploring the effects of actors' general social status on responsibility judgments.

11. Although consequence severity might not have a powerful impact on responsibility for wrongdofng, as previous research suggests, legal theory and practice indicate that it may have a more potent impact on punishment 
chotces. The present design allows us to examine effects of all variables on punishment as well as responsibility, although space considerations preclude discussion of punishment in the present paper.

1.2. In the equal status story, where a twin harmed his brother, the other participant was a friend; in the equal contract story, where a salesman sold a customer a defective car, the other was a fellow salesman; in the authority status story, where a mother harmed her child, the other was the father; and in the authority contract story, where a foreman's disregard for safety led to a worker's infury, the other was the foreman's boss. Note that 1.t might he argued that a husband wife relation ds actually a symmetrical one in this culture. However, it is questionable the extent to which this is true across all class and subcultural boundries. In addition, the study was also being conducted in Japan, and eventual comparisons between vitews of sex roles in the two countries were of interest to the two collaborating research teams. We shall present further data below from an additional story to bolster arguments involving status authority versus contract authority in light of possible critiques that differences are due to a wenk manipulation of authority fin the status setting.

1.3. It would appear that a more natural manipulation check for a good versus bad past pattern of hehavior would be a question that asked how 1ikely the actor was to do a simflar act in the ftiture. However, the answer to such a question 1 s confounded by the possible effects of sanctions on future action. In the crime story, for example, the actor might not repeat a bad action because imprisonment would prevent his doing so. Even in the less extreme role relation storles, sanctions might serve either to teach the offender or to prevent the offender from acting similarly again. Thus the most approprtate mantpulation check appeared to be an item that asked for a Bayestan-11ke prior probability of the action-- 1.e., whether it was predictable or not predictable given what was known about the actor. 13a. As has been noted in a prior paper (Hamilton, 1978), we wish to stress that stringency in standards of llability is not necessarily accompanted by actual stringency in sanctioning. N1though authorities may be normatively bound to higher, obligation-based standards, there 18 an excape-hatch involved in such standards. Just as it may be difficult to say when they have been met, it is correspondingly difficult to say when they have been seriously violated. Authorttative jobs may be accompanted by a great expanston in autonomously controlled time, in the sense of time before one is called on the carpet for nonperformance. Further, such jobs are accompanted by diffuse, occupant-controlled boundartes between work time and "time off." Finally, the standards themselves may be Inherently slippery ones of a morality of aspiration (Fuller, 1964), such that we are more comfortable in praising clear achlevement than in blaming fallure. What authoritative roles thus guarantee is increased freedom of action rather than improved behavior by actors.

14. Note that we have thus pulled apart two concepts that are combined in Heider's notion of the foreseeability level of responsibility attribution. Th1s pulling apart is characteristic of legal handling of negligence, however, in that simple negligence is distinguished from rccklessness in a variety of settings. Recklessness shades over into intentionality in legal rules, as well, such that the difference between presenting reckless acts for authorities and intentional acts for equals is probably not as great as it might seem. Legal rules such as felony murder statutes, for example, rest on the recklessness of engaging in a felony that might lead to loss of 11 fe for the victim. Hart (1968) discusses this issue in terms of the concept of oblique intention-- obviousiy a philosophical cousin of simple intentionality. 
15. The victim's involvement in each of these stories might be of interest in evaluating results. In the equal status story, the brothers were playing baseball with a friend. Either Billy, the protagon1st, or the friend (when other's influence was introduced) decided that it was B1lly's turn at bat. B1lly grabled the bat and the brothers began fighting. The brother was then hit with the bat; the hit was described as accidental in the low fintention conditions. B11.1.y had efther of ten or rarely gotten Into f.ights before. In the author.ty status story, a four-year-old child was crying and wouldn't sleep. The child's mother either went in to quiet him or was told by the father to do so (when other's influence was introduced). The child either struggled in her arms and slipped, hitting a chair (low intention) or was shoved into the chair (high intention). In elther case, the child was hurt on the chair. The mother was described as et.ther frequently or rarely getting angry at her child. Thus in both storfes the victim played some role in inttiating the actor's deed, although only to a degree that we felt was realistic in introducing stories about intra-famil tal harmdo ing.

1.6. We had no firm predictions about interactions of consequences severity with the role dimenstons, as prifor results for consequence sever1ty suggested that it might play only a weak role in determining responsibility. If differential. effects were to emerge, we felt that they would most plaustbly involve more emphasts on consequences in the non-role relationship settings of the auto accident and crime stories.

1.7. Part of an authority's role obligation, for example, might be to exercise a ligh degrece of foresight in overseeing events or the actions of others. Evidence that the actor did not exercise foresight is thus informative regarding both the authority's mental state per se and the authority's failinre to. live up to role demands.
18. Two somewhat weaker trends are evident for consequence severity and other's influence. Most strikingly, higher levels of mental state always produced perceptions of greater consequence severlty, suggesting that more intentional actions leads to a global evaluation of the event as worse. There was also a weaker trend for consequences of greater severity to be judged as more avoldable (though only in those stories where avoidability was rated as quite high). Other's influence, which had no manipulation check of its own, had diffuse but consistent effects on the checks for the other Items. If influence from another was present, the action tended to be evaluated as less purposive, and less predictable.

19. The conventional analysis strategy for anovadesigns ts to use the fully saturated model. We also repeated the analyses using only those effects that were significant in the initial analysis and found essentially identical coefficients. (Given that cell $\underline{n}$ 's were unequal, It was possible that results for the saturated and unsaturated models would differ, Indicating that some results were confounded by uneven distribution of cases among certaln cells.)

19a. Note that the "Avold" variable is dichotomous, and therefore technically should not be used as an endogamous var1able. However, use of "Purpose" alone would lead to Inappropriate conclustons regarding the use of mental state information given the differences between stories for equals and authorities. Therefore we chose to include both manipulation checks as a better reflection of the true relationships in these data. In addition, in these figures we have omitted the two-headed arrow between the Purpose and Avo1d variables to simplify reading the models, as that arrow is theoretically uninteresting. The correlation between the two is only .25, so that multicollinearity does not threnten any concluslons drawn.

20. The direct path from mental state with purposiveness and avoldability controlled 
mitglit seem to be an odd ent lty. We shall. show below, however, that it results from expected differences between stories with equal and authoritative actors.

21. Table 3 also indicated four other significant effects: an interaction of hierarchy and solidarity; a three-way interaction of consequences, other's influence and hlerarchy; and one four-way and one flve-way interaction. All of these effects were small and unstable across replications as well as being unpredicted. They can, therfore, safely be ignored. They serve to illustrate that use of multiple observations from respondents without a control strategy such as the replication one used here can produce results that would not prove to be stable across studies.

22. As one would expect, the mallback respondents were significantly more 1.1.kel.y to be white, female, and high.ly educated than was the overall sample. They are thus more simflar both to survey quota samples and to the coll.lege subject pools of other studtes than are the respondents taken as a whole. Yet mafliback respondents did not differ significantiy from nonrespondents in their reactions to the stories in the main design, and so their answers to the mallback story are not 1ikely to differ systematically from those that would be produced by the whole sample. Inference to the whole sample, of course, ts nevertheless unwarranted.

23. The project has fnvolved collaboration with an interdisciplinary team of Jnpanese scholars since the fall of 1976 . Intetal ptans for the D.A.S. were made after consultation with Professor Yoko flosol and Items were developed with feedhack from her and Professors Zensuke Ishimura and Kazuhiko Tokoro. Durl.ng the course of plannl.ng the Yokoliama study, the Japanese group expanded to Include Professors Nozomu Matsubara, Nobulıo Tomita, and Tsuyochi Kato, and Dr. Haruo Nishimura. The Japanese research group's plans for the Kanazawa study, in turn, were made after consultation with us.
REFERENCES

Alves, W. and P. Rossi

1978 "Who should get what? Fairness fudgments of the distribution of earnings." American Journal of Soctology 84: 541-564.

Arkkelin, D., Oakley, T., and C. Mynatt

1979 "Effects of controllable versus uncontrollable factors on responsibility attributions: A single-subject approach." nal of Personality

Biddle, B.J. and E.J. Thomas (Eds.) 1966 Role Theory: Concepts and Research. New York: Wiley.

B1ack, D

1976 The Behavior of Law. New York: Academic Press.

1979 "Common sense in the sociology of law." American Soctological. Review 44: 18-27.

B.lau, P.

1964 Exchange and Power in Soctal Life. New York: John Willcy and Sons.

Brown, $R$

1965 Soc1al Psychology. New York: Free Press.

Dahrendorf, R.

1959 Class and Class Conflict in Industrial Society. Stanford: Stanford University Press.

Dinstein, Y.

1971 The Defense of Obedience to Orders In International Law. Leyden, Netherlands: A.W. Sifthof.

Emerson, R.M. Judging Delinquents: Context and Process in Juventle Court.

1969 Judging Dellnquents: Context

Fincham, F. and J. Jaspars

forthcoming "Attribution of responsibility to the self and others in children and adults." Journal of Personality and Social Psychology, in press.

Fishbein, M. and A. Ifzen

1973 "Attrtbutton of responstbility. A theoretical note." Journal of Experimental Social Psychology 9: 148-155.

Gilligan, C. "In a different votce: Women's conception of the self and of

1977 "In a different volce: Women's conception of the
morality." Harvard Education Review 47.: 481-51.7

Gluckman, M. The Judficial Process Among the Barotse of Northern Rhodesta.

1967 The Judter: Manchester University Press. 
Gott fredson, M.R. and M.J. Hindelang

1979a "A study of The Behavior of Law." American Sociological Review 44: 3-18.

1979b "Theory and research in the soctology of law." American Snctological Revtew 44: 27-37.

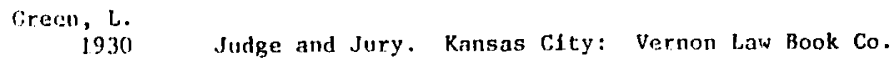

Hamllicon, v.l..

1978 "Who is responstble? Toward a social psychology of responsibility attribution." Soc1al Psychotogy 41: 316-328.

Harris, B. "Developmental differences in the attribution of responsibility."

1.977 "Developmental differences in the attrth
Developmental. Psychology 13: 257-265.

Hart. H.L.A. Puntishment and Responstbility: Essays in the PhIlosophy of
1968

1968 Punishment and Responstbility: Essays in

Hart., H.L.A. and Honore

1959. Cxasation in the Law. Oxford: Clarendon Press.

1978 "Moral evaluations and fudgments of responsibility." Personality and Soctal Psychology Bulletin 4: 583-588.

Helder, F. The Psychology of Interpersonal Relations. New York: Wiley.

Hoffman, M.

1975 "Sex differences in moral internalization and values." Journal of Personality and Social Psychology 32: 720-729.

Ialsso, G. and P.H. Ross

1977 "Distributive Justice and earned fncome." American Soctological Review 42: 639-65.1.

Ke.11cy, II.II.

1967 "Attribution theory in social psychology." In L. Berkowitz (Ed.), Nebraska Sympositum on Motivation 15: 192-238.

1973 "The process of causal attribution." American Psychologist 28: $1.07-128$

Kerckliof $\mathrm{E}, \mathrm{A}$

1.973 Soctalization and Soctal. Class. Englewood C11ffs, N.J.: PrenticeHal.1.

Kolliberg, L.
1.969 sociallzation." In Handbook of Soctalization
D.A. Goslin, (Ed.). Chicago: Rand-McNally.

Kohn, M.

Class and Conformity: A Study of Values. Homewood, Illinols: Dorsey Press.

Lickona, T. (Ed.)

1976 Moral Development and Behavior. New York: Holt, Rlnehart.

Llewelen, $K$. and $A$ : Hoebe 1

1949 The Cheyenne Way. Nornan: Untversity of Ok1ahoma Press.

Macaulay, S.

1963 "Non-contractual relations in business: A preliminary study." American Sociological Review 28: 55-67.

Malne, H.

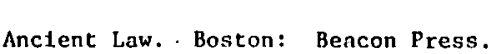

1969 Law in Culture and Society. Chicago: Aldtne.

Nock, S, and P. Rossi

1978 "Ascription versus achievement in the attribution of family social status." American Journal of Sociology 84: 565-590.

Nonet, $P$.

1969 Administrative Justice. New York: Russell Sage Foundation.

Parsons, T.

1951 The Soc1al System. New York: Free Press.

Plaget, J.
1965

The Moral Judgment of the Chl1d. New York: Free Press.

Ross, H.L.

1970

Settled Out of Court: The Social Process of Insurance Clatms Adjustments. Chicago: Aldine.

Sampson, E.E.

1978

"Scientific paradigms and social values: Wanted - - a scientific revolution." Journal of Personality and Socfal Psychology 36:

Sarbin, T.R. and V.L. Allen

1968 "Role theory." In Handbook of Social Psychology, Vol. 1

(G. Lindzey and E. Aronson, Eds.). Reading. Mass.: Addison-wesley.

Shapo, M. The Duty to Act: Tort Law, Power and Public Pollcy. Austin: University of Texas Press.

Shaver, K.G.

1970

"Effects of severity and relevance on the responsibility

assigned for an accident." Journal of Personality and Soclal Psychology 14: 110-11.3. 


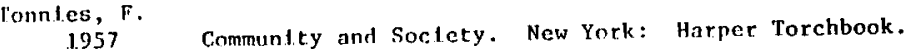

Vfdmar, N. and L. Crinklaw of responsibility for an accident: A methodological "Canadian Journal of Behavioral Sctence 6: $11.2-130$.

Walster, E.

"Assignment of responsibility for an accident." Journal of Personaltey and Soctal Psychology 3: 73-79.

Weber, M. The Theory of Social and Economic Organization. (T. Parsons, d.) New York: Free Press.

1962 "Some notes on the functional theory of stratification." Pollsh Soctological Bulletin 3-4: 28-38. (Reprinted in R. Bendix and S.M. Lipset (Eds.) Class, Status, and Power (2nd ed.). New York: Free Press.

Wolr, E.

1969 Peasant Wars of the Twentieth Cent:ury. New York: Harper and Row.
Summary of the study design.

Table 1

\section{Solidarity between Actor-Victin}

\begin{tabular}{|c|c|c|}
\hline & $\begin{array}{c}\text { Status } \\
\text { Relationship }\end{array}$ & $\begin{array}{c}\text { Contract } \\
\text { Relationship }\end{array}$ \\
\hline $\begin{array}{l}\text { Equality } \\
\text { Hierarchy } \\
\text { between }\end{array}$ & $\begin{array}{c}\text { TWINS } \\
\text { Varfations In: } \\
\text { Mental State } \\
\text { Consequences } \\
\text { Past Pattern } \\
\text { Other's Influence }\end{array}$ & $\begin{array}{l}\text { SELLER-BUYER } \\
\text { Variations In: } \\
\text { Mental State } \\
\text { Consequences } \\
\text { Past Pattern } \\
\text { Other's Influence }\end{array}$ \\
\hline Authority & $\begin{array}{l}\text { MOTHER-CHILD } \\
\text { Variations In: } \\
\text { Mental State } \\
\text { Consequences } \\
\text { Past Pattern } \\
\text { Other's Influence }\end{array}$ & $\begin{array}{l}\text { BOSS-WORKER } \\
\text { Variations In: } \\
\text { Mental State } \\
\text { Consequences } \\
\text { Past Pattern } \\
\text { Other's Inf luence }\end{array}$ \\
\hline
\end{tabular}


TABLE 2 (continued)

TABLE 2

Effects of experimental manipulations on manipulation checks by story. ${ }^{a}$

a) Equal/status

\begin{tabular}{|c|c|c|c|c|}
\hline & Mental State & Past Pattern & Consequences & Other's Influence \\
\hline $\begin{array}{r}\text { Purposiveness } \\
t\end{array}$ & $-8.00^{e}$ & $-2.811^{\mathrm{c}}$ & .05 & .15 \\
\hline$r$ & .30 & .11 & -.00 & .01 \\
\hline \multicolumn{5}{|l|}{ Avotdabilifty } \\
\hline$x^{2}$ & 3.32 & .32 & $4.44^{b}$ & 1.51 \\
\hline$\gamma$ & .23 & .07 & .27 & -.16 \\
\hline \multicolumn{5}{|l|}{ Predfctablllty } \\
\hline$x^{2}$ & 1.96 & $83.00^{\mathrm{e}}$ & .84 & $6.04^{b}$ \\
\hline$\gamma$ & .111 & .66 & -.08 & -.20 \\
\hline \multicolumn{5}{|l|}{ Serlousness } \\
\hline$\underline{t}$ & $-3.69^{d}$ & $-2.03^{b}$ & $-6.41^{\mathrm{e}}$ & .65 \\
\hline$r$ & .14 & .08 & .24 & -.03 \\
\hline
\end{tabular}

b) Equal/contract

\begin{tabular}{|c|c|c|c|c|}
\hline & Mental State & Past Pattern & Consequences & Other's Influence \\
\hline $\begin{array}{c}\text { Purpostueness } \\
\underline{t}\end{array}$ & $-10.03^{e}$ & $-4.02^{d}$ & -1.51 & $3.16^{c}$ \\
\hline$r$ & .37 & .16 & .06 & -.12 \\
\hline $\begin{array}{r}\text { Avoldabllitey } \\
x^{2}\end{array}$ & .09 & .10 & $6.16^{b}$ & .09 \\
\hline$\gamma$ & .06 & .06 & .49 & -.06 \\
\hline \multicolumn{5}{|l|}{ Predtctnblitty } \\
\hline$x^{2}$ & 1.79 & $114.77^{e}$ & .50 & $17.18^{\mathrm{e}}$ \\
\hline$\gamma$ & .11 & .72 & -.02 & .32 \\
\hline \multicolumn{5}{|l|}{ Scriousness } \\
\hline t & $-2.37^{b}$ & -1.67 & $-8.44^{e}$ & -1.75 \\
\hline $\mathrm{r}$ & .09 & .07 & .32 & .07 \\
\hline
\end{tabular}

c) Authordty/status

\begin{tabular}{|c|c|c|c|c|}
\hline & Mental State & Past Pattern & Consequences & Other's Influence \\
\hline \multicolumn{5}{|l|}{ Purposiveness } \\
\hline$\underline{\mathrm{t}}$ & $-4.80^{\mathrm{e}}$ & $-3.43^{\mathrm{d}}$ & -1.30 & -.93 \\
\hline $\mathbf{r}$ & .18 & .13 & .05 & .04 \\
\hline \multicolumn{5}{|l|}{ Avoldability } \\
\hline$x^{2}$ & $49.44^{e}$ & $4.44^{\mathrm{b}}$ & 1.59 & .06 \\
\hline$\gamma$ & .60 & .19 & .1 .1 & .02 \\
\hline \multicolumn{5}{|l|}{ Predictability } \\
\hline$x^{2}$ & $10.48^{c}$ & $85.10^{\mathrm{e}}$ & 2.20 & .69 \\
\hline$\gamma$ & .29 & .75 & .14 & .08 \\
\hline \multicolumn{5}{|l|}{ Seriousness } \\
\hline$\underline{t}$ & -2.88 & $-3.53^{\mathrm{d}}$ & $-7.46^{\mathrm{e}}$ & -1.96 \\
\hline r & .11 & .14 & .28 & .08 \\
\hline
\end{tabular}

d) Authority/contract

\begin{tabular}{rcccc} 
& Mental State & Past Pattern & Consequences & Other's Influence \\
\cline { 2 - 5 } $\begin{array}{r}\mathrm{t} \\
\mathrm{r}\end{array}$ & $-9.39^{\mathrm{e}}$ & $-3.08^{\mathrm{c}}$ & .23 & 1.82 \\
Purposiveness & .34 & .12 & -.01 & -.07 \\
Avoidabi11ty & & & & \\
$\chi^{2}$ & $18.40^{\mathrm{e}}$ & $5.22^{\mathrm{b}}$ & .20 & 1.42 \\
$\gamma$ & .58 & .32 & -.06 & -.17 \\
Predictabi1tty & & & & \\
$\chi^{2}$ & $14.88^{\mathrm{d}}$ & $69.31^{\mathrm{e}}$ & .18 & 3.60 \\
$\gamma$ & .30 & .60 & .03 & -.1 .5 \\
Seriousness & & & & -.67 \\
$\mathrm{t}$ & -1.26 & -.81 & $-8.97^{\mathrm{e}}$ & -.03 \\
$\mathrm{r}$ & .05 & .03 & .33 &
\end{tabular}



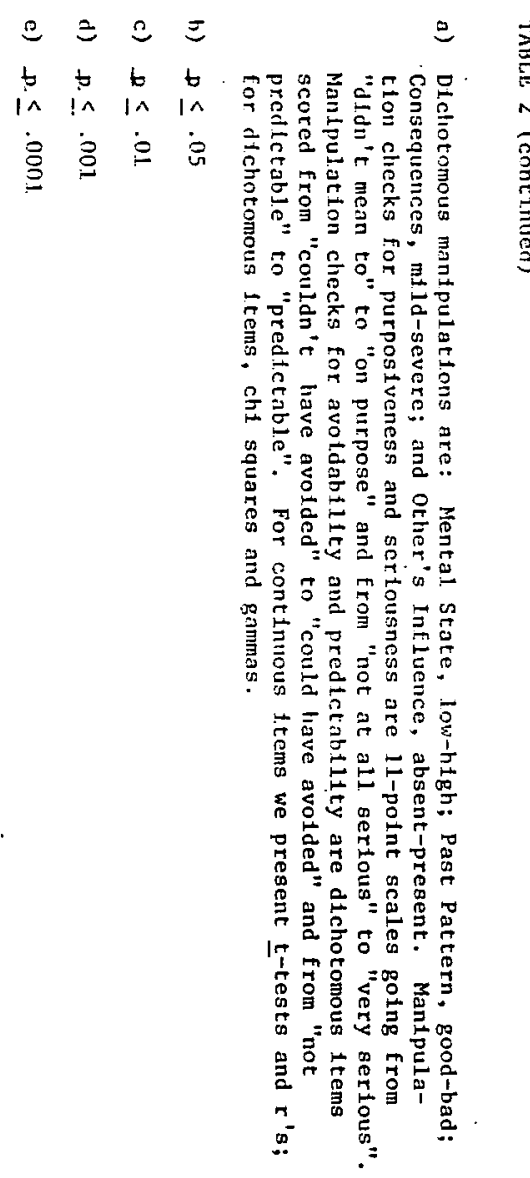

Table 3

Analysis of varlance for responsibility: Summary of significant effects from saturated $\left(2^{6}\right)$ model for extended file plus coefficients from quasi-Independent replications. ${ }^{a}$

\begin{tabular}{|c|c|c|c|c|c|c|c|}
\hline \multirow[b]{2}{*}{ Effect } & \multicolumn{3}{|c|}{ Extended File } & \multicolumn{3}{|c|}{ Replications: Unstandardized } & \multirow{2}{*}{$\frac{\text { d Coeffictent }}{4}$} \\
\hline & d.f. & $\mathbf{F}$ & $\begin{array}{l}\text { Unstandardized } \\
\text { coefficient }\end{array}$ & 1 & 2 & 3 & \\
\hline Mental State (M) & 1 & $127.5^{\mathrm{e}}$ & .63 & .70 & .39 & .77 & .61 \\
\hline Consequences (c) & 1 & $5.7^{b}$ & .13 & .01 & .03 & .30 & .22 \\
\hline Past Pattern (P) & 1 & $28.0^{\mathrm{e}}$ & .30 & .27 & .51 & .21 & .28 \\
\hline Other's Influence ( 0 ) & 1 & $7.6^{\mathrm{c}}$ & -.15 & -.13 & -.12 & -.12 & -.22 \\
\hline Hierarchy (H) & 1 & $72.2^{e}$ & -.48 & -.45 & -.51 & -.46 & -.52 \\
\hline Solidarity (S) & 1 & $162.8^{e}$ & .72 & .77 & .77 & .84 & .44 \\
\hline $\mathrm{M} \times \mathrm{H}$ & 1 & $13.6^{\mathrm{d}}$ & -.21 & -.22 & -.21 & -.13 & -.25 \\
\hline $\mathrm{O} \times \mathrm{H}$ & 1 & $13.9^{\mathrm{d}}$ & .21 & .02 & .12 & .40 & .32 \\
\hline H $\times S$ & 1 & $7.7^{\mathrm{c}}$ & -.16 & -.09 & -.25 & -.05 & -.14 \\
\hline$M \times C \times S$ & 1 & $6.0^{\mathrm{b}}$ & -.14 & -.16 & .04 & -.18 & -.15 \\
\hline$C \times 0 \times s$ & 1 & $4.0^{b}$ & -.11 & -.05 & -.09 & -.21 & -.04 \\
\hline$C \times P \times H \times S$ & 1 & $5.6^{\mathrm{b}}$ & .13 & .01 & .16 & .16 & .09 \\
\hline$C \times P \times O \times H \times S$ & 1 & $4.1^{b}$ & .11 & .21 & .25 & -.13 & .11 \\
\hline
\end{tabular}

Error 2551

Grand Mean $=8.29$ (Responsibility varlable recoded to $1-$ to -11 from $0-$ to -10 original scale for computational convenience.)

3) The Independent variables were entered as the following contrast-coded effects: Mental State, low-high; Consequences, mild-severe; Past Pattern, good-bad; Other's Influence, absent-present; Hierarchy, equalauthority; and Solidarity, stacus-contract. The unstandardized coefficlents for these main effects and all interactions compare means against "high" cells. Thus they should be doubled in size to obtain the overall effect for each variable.

b) $p \leq .05$

c) $p \leq .01$

d) 5.001

e) $\mathrm{p} \leq .0001$ 
Tab1e 5

Table 4

Interaction of mental state, solidarity, and consequences: Effects on attributed rcsponstibility in extended file analysts.a

\begin{tabular}{|c|c|c|c|c|}
\hline & & Cons & & \\
\hline & $M 11 \mathrm{~d}$ & & & \\
\hline & & Men & & \\
\hline & Low & Hitgh & Low & H1gh \\
\hline Stat:us & $\begin{array}{c}6.85 \\
(328)\end{array}$ & $\begin{array}{r}7.90 \\
(323)\end{array}$ & $\begin{array}{l}6.81 \\
(334)\end{array}$ & $\begin{array}{r}8.70 \\
(320)\end{array}$ \\
\hline Contract & $\begin{array}{c}8.29 \\
(334)\end{array}$ & $\begin{array}{c}9.57 \\
(327)\end{array}$ & $\begin{array}{c}8.64 \\
(325)\end{array}$ & $\begin{array}{c}9.60 \\
(324)\end{array}$ \\
\hline
\end{tabular}

Mental. State-Solidarity interaction, milld consequences:

$$
\mathrm{F}(1,1308)=.44, \mathrm{n.s} \text {. }
$$

liental State-Solidarity finteraction, severe conscquences

$$
F(1,1298)=8.80, p=.003 .
$$

a) Cells contain mean score for responsibility, ranging from 1 (not at all respons Ible) to 1.1. (fully responsible); it was rescaled from original 0-to-1.0 scale for computational conventence. Cel.1 $\mathrm{n}^{\prime} \mathrm{s}$ are presented in parentheses below means.
Interaction of mental state and hierarchy: Effects on attributed responsibility (Resp.) and purposiveness (Purp.) in extended f1le analysis.

Mental State

\begin{tabular}{|c|cc|cc|}
\multicolumn{1}{c|}{ Low } & \multicolumn{3}{c|}{ High } \\
\cline { 2 - 5 } Equal & $\frac{\text { Resp }}{8.36}$ & $\frac{\text { Purp }}{5.98}$ & $\frac{\text { Resp }}{9.20}$ & $\frac{\text { Purp }}{8.42}$ \\
Hierarchy & $(660)$ & $(654)$ & $(646)$ & $(644)$ \\
\cline { 2 - 5 } & $\frac{\text { Resp }}{6.94}$ & $\frac{\text { Purp }}{2.59}$ & $\frac{\text { Resp }}{8.69}$ & $\frac{\text { Purp }}{4.46}$ \\
& $(661)$ & $(666)$ & $(648)$ & $(645)$ \\
\hline
\end{tabular}

a) Cel1s contain means for responsibility, ranging from 1 (not at all responsible) to 11 (fully responsible); and for purposiveness, rang ing from 1 (d1dn't mean to) to 11 (did on purpose). Both variables were rescaled from original $0-$ to-1U scales for computational conventence. $N^{\prime} s$ for both variables are presented in parentheses below means. 
Effects of mental state and hierarchy on responstbility stratified by respondent's judgsment of purposiveness and by tinfluence from another party.

A) Accidental Acts (Purpostveness from 0-2 on 1.1-point scale)

\begin{tabular}{|c|c|c|}
\hline & \multicolumn{2}{|c|}{$\begin{array}{c}\text { Influence } \mathrm{f} x \mathrm{xm} \text { ther } \\
\text { Absent }\end{array}$} \\
\hline & \multicolumn{2}{|c|}{ Itieratchy } \\
\hline & Equn.1. & Authority \\
\hline Low & 7.01 & $\begin{array}{r}6.79 \\
(036)\end{array}$ \\
\hline iligh & $\begin{array}{r}6.31 . \\
(35)\end{array}$ & $\begin{array}{l}8.1 .7 \\
(163)\end{array}$ \\
\hline
\end{tabular}

Hierarchy $(H): F(1,532)=4.83, \mathrm{P}<.05$ Mental. State $(M): F(1,532)=.84$, n.s.

$11 \times M: F(1,532)=7.73, p<.01$.

\section{Influence from other}

Fresent

Hierarchy

\begin{tabular}{|c|c|c|}
\hline \multirow{3}{*}{$\begin{array}{l}\text { Nicntal } \\
\text { State }\end{array}$} & Equa1 & Authority \\
\hline & $\begin{array}{l}6.86 \\
(104)\end{array}$ & $\begin{array}{l}6.13 \\
(250)\end{array}$ \\
\hline & $\begin{array}{r}6.86 \\
(49)\end{array}$ & $\begin{array}{l}7.51 \\
(163)\end{array}$ \\
\hline
\end{tabular}

H.erarchy $(H): F(1,562)=.01, n . s$ Mental State $(M): F(1,562)=4.39, \mathrm{~g}<.05$ $H \dot{X} M: F(1,562)=4.37, P<. .05$

B) Careless Acts (Purpostiveness from 3-7 on 1.1-point scale)

$$
\begin{gathered}
\text { Inf Luence from other } \\
\text { Absent }
\end{gathered}
$$

HLerarchy

\begin{tabular}{|c|c|c|}
\hline & Equa1 & Author 1ty \\
\hline Low & $\begin{array}{l}8.09 \\
(115)\end{array}$ & $\begin{array}{r}8.60 \\
(72)\end{array}$ \\
\hline II.gh & $\begin{array}{r}8.09 \\
(65)\end{array}$ & $\begin{array}{c}9.27 \\
(92)\end{array}$ \\
\hline
\end{tabular}

H: $F(1,340)=9.46, E<.01$.

N: $F(1,340)=1.53$, n.s. II M: $F(1,340)=1.48$, n.s.

\section{Influence from other} Present

Hierarchy

\begin{tabular}{|c|c|c|}
\hline & Equal & Author1ty \\
\hline Low & $\begin{array}{c}8.55 \\
(1.18)\end{array}$ & $\begin{array}{r}6.93 \\
(58)\end{array}$ \\
\hline$H 1 \mathrm{gh}$ & $\begin{array}{l}9.12 \\
(82)\end{array}$ & $\begin{array}{c}8.78 \\
(82)\end{array}$ \\
\hline
\end{tabular}

$H: F(1,336)=13.35, \mathrm{R}<.001$

M: $F(1.336)=20.34, p<.0001$

H $\times M: F(1,336)=5.67, \mathrm{p}<.05$
C) Intended_Acts (Purposiveness from 8-10 on 11-point scale)

\begin{tabular}{|c|c|c|}
\hline & \multicolumn{2}{|c|}{$\begin{array}{c}\text { Influence from other } \\
\text { Absent }\end{array}$} \\
\hline & \multicolumn{2}{|c|}{ Hierarchy } \\
\hline & Equal & Authority \\
\hline Low & 10.01 & 9.88 \\
\hline $\mathrm{HIgh}$ & $\begin{array}{r}9.89 \\
(211)\end{array}$ & $\begin{array}{r}10.33 \\
(70)\end{array}$ \\
\hline
\end{tabular}

Inf luence from other Present

Herarchy

\begin{tabular}{|c|c|c|}
\hline \multirow{3}{*}{$\begin{array}{l}\text { Nental } \\
\text { State }\end{array}$} & Equal & Authority \\
\hline & $\begin{array}{r}9.53 \\
(101)\end{array}$ & $\begin{array}{c}9.78 \\
(18)\end{array}$ \\
\hline & $\begin{array}{r}10.10 \\
(195)\end{array}$ & $\begin{array}{l}9.93 \\
(72)\end{array}$ \\
\hline
\end{tabular}
H: $F(1,415)=.29$, n.s.
M: $F(1,415)=.32$, n.s.
H $\times$ M: $F(1,415)=.97$, n.s.

H: $F(1,382)=.01$, n.s.

M. $F(1,382)=1$.

H X M: $F(1,382)=.43$, n.s. a) Cells contain mean score for responsibility, rang ing from 1 (not at all responsible) to '11 (fully responsible); it was rescaled from original 0-to-10 scale for computational conventence. Cell n's are presented in parentheses below means. 
Interaction of other's influence and hierarchy in extended file analysis. ${ }^{a}$

Other's Inf luence

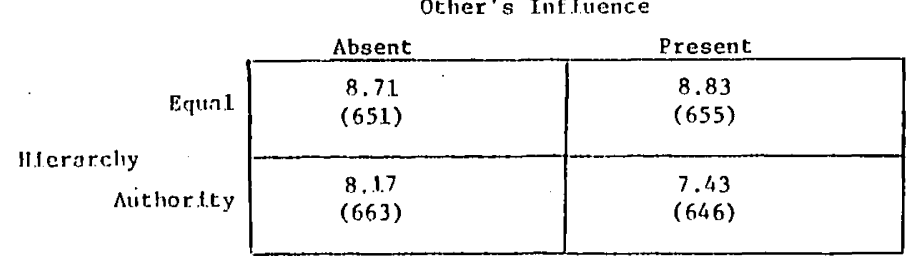

a) Cejl neans are for the dependent vartable responsibility, recoded to I-to-11 scale. $\mathrm{N}$ 's are presented In parentheses below means.
Means for variables significantly affecting relative responsibility of actor and other in extended file analysis.

\begin{tabular}{c|c|c|}
\multicolumn{2}{c}{ Equal } & Herarchy \\
\cline { 2 - 3 } Status & $\begin{array}{c}1.80 \\
(321)\end{array}$ & $\begin{array}{c}2.96 \\
(328)\end{array}$ \\
\cline { 2 - 3 } Solidarity & $\begin{array}{c}2.60 \\
(327)\end{array}$ & $\begin{array}{c}3.04 \\
(319)\end{array}$ \\
\cline { 2 - 3 } & & \\
\hline
\end{tabular}

\section{Results of anova}

Herarchy (H): $F(1,1263)=137.2, \mathrm{P}<.0001$

Solidarity $(\mathrm{S}): \mathrm{F}(1,1263)=42.3, \mathrm{P}<.0001$

H X S : $F(1,1263)=27.6, \mathrm{~g}<.0001$

a) Relative responsibility was a composite varlable scored from J (other not at all responsible) to 5 (other completely responsible). Cells contain means for this varfable with $\underline{n}^{\prime} s$ in parentheses below. 
Tab1e 9

Summary of signfficant results from $2^{4}$ analysts of varfance for responstbility in a malliback story where actor-other role relations were varied.

\begin{tabular}{lrrr} 
Effect & d.f. & \multicolumn{1}{c}{ F } & Unstandarized Coefficient \\
\hline Solidarity (S) & 1 & $7.9^{\mathrm{C}}$ & -.47 \\
Hierarchy (II) & 1 & $87.4^{\mathrm{e}}$ & -1.55 \\
Control (C) & 1 & $8.0^{\mathrm{C}}$ & -.47 \\
$\mathrm{~S} \times$ HI & 1 & $6.1^{\mathrm{b}}$ & .41 \\
H $\times$ C & 1 & $4.4^{\mathrm{b}}$ & .34 \\
Error & 333 & & \\
Grand Hean $=7.05$ & & &
\end{tabular}

a) Main cffects included in the model were Mental. State, low-high; Solidarity, other party was status-contract; Herarchy, other was equal-authority; and Control, other suggested-told. Responstbility was recoded to 1-to-11 scalce from or Iginal 0 -to-1.0 varlable. Fffects were contrast coded to reflect the difference between means and "high" cells, and thus should be doubled to reflect the overall ef fect of each varlable.

b) $\mathrm{R} \leq .05$

c) $\mathrm{p} \subseteq .01$

d) $\mathrm{p} \leq .001$

e) $\mathrm{p} \leq .000 \mathrm{~L}$
Table 10

Interaction effects for mallback story where role relations of actor and Interaction effects

A. Herarchy-Control Interaction

Herarchy

\begin{tabular}{|c|c|c|}
\hline & Equal & Authority \\
\hline Suggested & $\begin{array}{r}8.67 \\
(88)\end{array}$ & $\begin{array}{r}6.33 \\
(84)\end{array}$ \\
\hline To1d & $\begin{array}{r}8.43 \\
(92)\end{array}$ & $\begin{array}{l}4.59 \\
(85)\end{array}$ \\
\hline
\end{tabular}

B. Herarchy-Solidarity Interaction

\begin{tabular}{c|c|c|}
\multicolumn{2}{c}{ H1erarchy } \\
\cline { 2 - 3 } Status & Equa1 & Authority \\
\cline { 2 - 3 } Solidarity & $\begin{array}{c}8.59 \\
(100)\end{array}$ & $\begin{array}{c}6.40 \\
(90)\end{array}$ \\
\hline Contract & $\begin{array}{c}8.50 \\
(80)\end{array}$ & $\begin{array}{c}4.38 \\
(79)\end{array}$ \\
\cline { 2 - 3 } & &
\end{tabular}

a) Cells contain mean responsibility score on 1-to-11 scale and n's in parentheses below means. 
Figure $1^{a}$

\section{Figure Captions}

Pigure 1. Direct and Indirect effects of mental state, solidarity, and hierarchy on responsibility at:tribution with other's influence absent versus present.

Figure 2. Direct and Indirect effects of actor's manipulated mental state on responslibility of equals versus authorities.

Flgure 3. Direct and indirect effects of actor's past pattern of behavior on responsthitifty of equal.s versus authortitles.
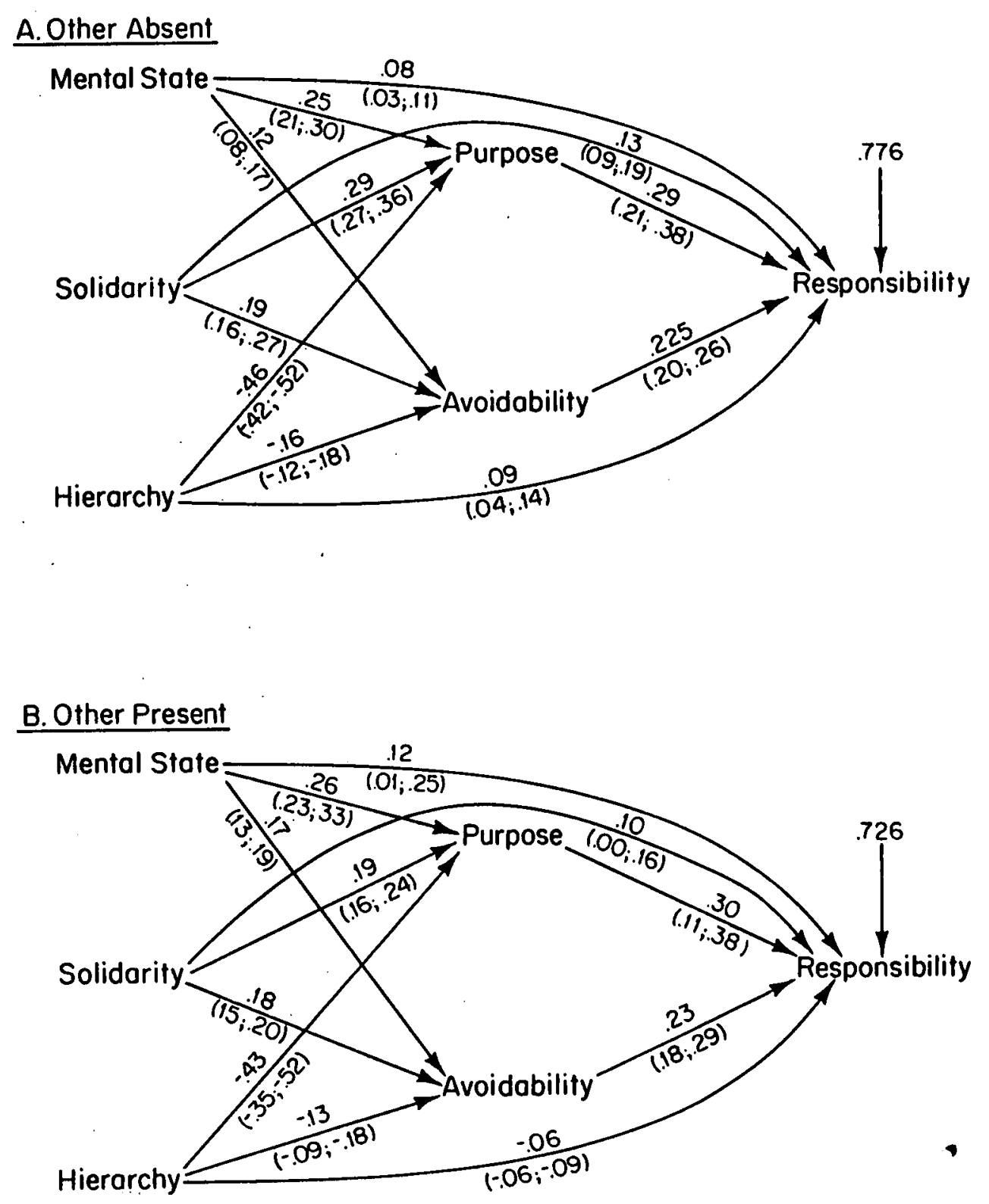
a) Vart.nbles were coded as follows: Mental State, low-Hlgh; Solldarity, StatusContract: Hierarchy, Equal-Authority; Purpose, "didn't mean to-did on purpose; Avoldnbilitty, "could not have avolded-could have avoided"; Responsibility, "not at a1.1. responstble-fully responsible." Standardized coefficients for cxtended file analysis are presented above each arrow; all were significant at the $p<.05$ tevel or better. The low and high coeffictents from the four quast-independent replfications are presented below each line in parentheses.
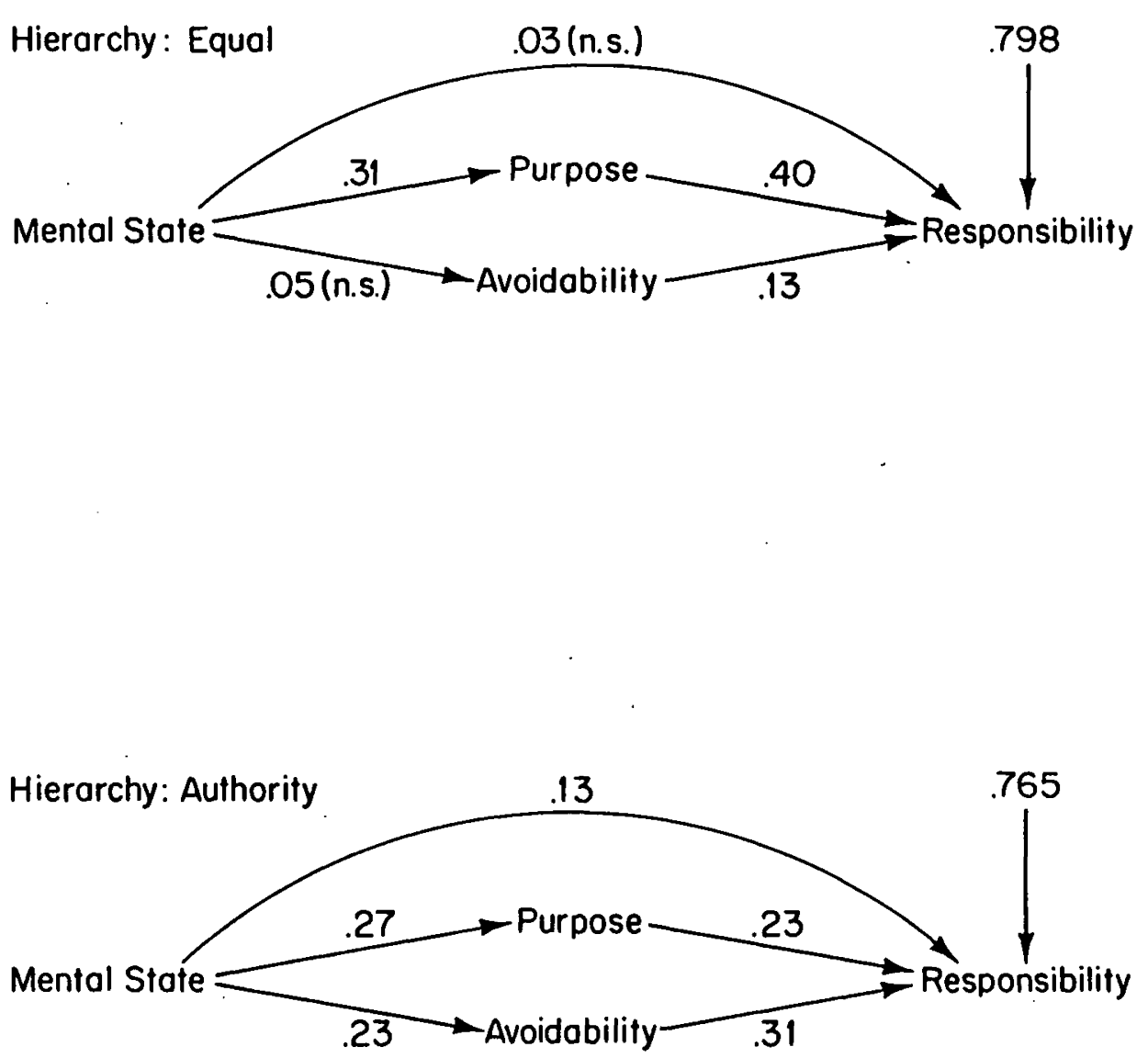

a) Variables were coded as follows: Mental State, Low-High; Purpose, "didn't mean todid on purpose"; Avoldability, "could not have avolded-could have avotded"; Responsibility, "not at all responsible-fully responsible." Standardized coefficients from the extended file analysts are presented with indications where they are not significant. 


\section{Figure $3^{a}$}
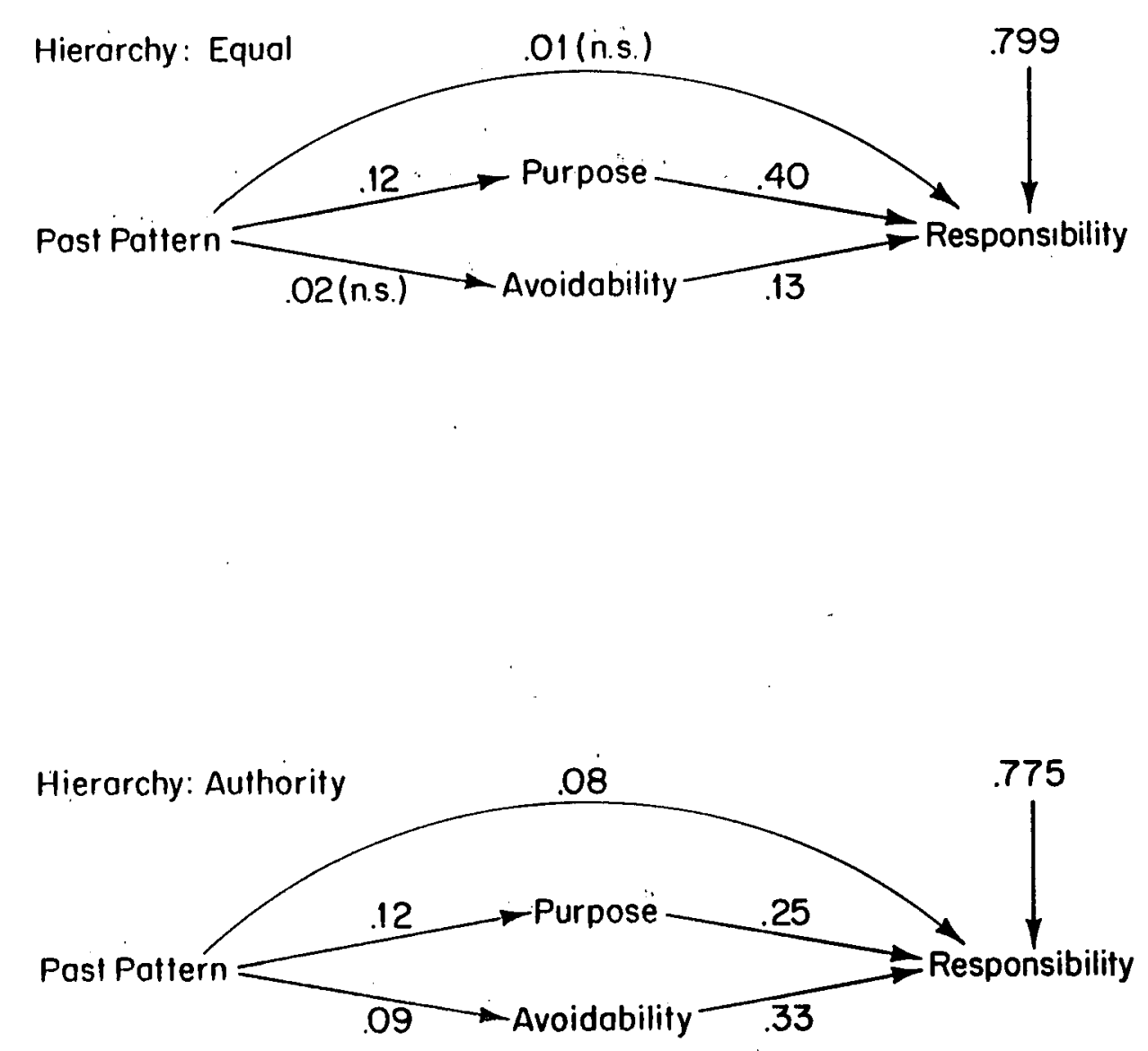

i) Varlahlle:s were coded as follows: Past Pattern, Good-Bad; Purpose, "didn't mean todid an purpose"; Avoldabtlity, "could not have avotded-could have avolded"; Responstbflity, "not at alli responsthle-fully responstble." standardized coefficients from the extended file analysis are presented, with indications where they are not signiftcant. 
WORKING PAPERS OF THE CENTER FOR RESEARCH ON SOCIAL ORGANIZATION

The Center for Research on Social Organization is a facility of the Department of Sociology, University of Michigan. Its primary mission is to support the research of faculty and students in the department's Social Organization graduate program. CRSO Working Papers report current research and reflection by affiliates of the Center; many of them are published later elsewhere after revision. Working Papers which are still in print are available from the Center for a fee of 50 cents plus the number of pages in the paper (99 cents for a $49-p a g e$ paper, etc.). The Center will photocopy other papers at cost (approximately five cents per page). Recent Working Papers include:

188 "Resource Mobilization, Repression, and Working-Class Protest: Lyon, France Under the Second Republic and the Second Empire," by Robert Liebman, forthcoming.

189 "Did the Cake of Custom Break?" by Charles Tilly, December 1978, 47 pages.

190 "Women and Collective Action in Industrializing France, 1870-1914," by Louise A. Tilly, January 1979, 32 pages.

191 "The Rise and Fall of the Bourgeois Family, as Told by Lawrence Stone and Christopher Lasch," by Charles Tilly and Louise A. Tilly, January 1979, 11 pages.

192 "The Family Wage Economy of á French Textile City, Roubaix, 1872-1906," by Louise A. Tilly, January 1979,23 pages.

193 "Sociology, Meet History," by Charles Tilly, February 1979, 97 pages.

194 "Administrative Regulation and Industry: A Sociologtcal Perspective," by James B. Lowenthal, Michae1 A. Berger, and Mayer N. Zald, March 1979, 157 pages.

195 "Sinews of War," by Charles Tilly, March 1979, 25 pages.

196 "Trends in Policy Making and Implementation in the Welfare State: A Preliminary Statement," by Mayer N. Zald, May 1979, 20 pages.

197 "Social Movements and National Politics," by Charles Tilly, May 1979, 30 pages.

Request copies of these papers, the complete:list of : Working:-Papers, lists of other Center reprints, or further information about Center activities from:

Center for Research on Social Organization

University of Michigan

330 Packard Street

Ann Arbor, Michigan 48109 